\title{
Emerging cellular and molecular mechanisms underlying anticancer indications of chrysin
}

\author{
Marjan Talebi ${ }^{1}$, Mohsen Talebi ${ }^{2,3}$, Tahereh Farkhondeh ${ }^{4,5}$, Jesus Simal-Gandara ${ }^{6}$, Dalia M. Kopustinskiene ${ }^{7}$, \\ Jurga Bernatoniene ${ }^{7}$ and Saeed Samarghandian ${ }^{8^{*}}$ (I)
}

\begin{abstract}
Chrysin has been shown to exert several beneficial pharmacological activities. Chrysin has anti-cancer, anti-viral, antidiabetic, neuroprotective, cardioprotective, hepatoprotective, and renoprotective as well as gastrointestinal, respiratory, reproductive, ocular, and skin protective effects through modulating signaling pathway involved in apoptosis, oxidative stress, and inflammation. In the current review, we discussed the emerging cellular and molecular mechanisms underlying therapeutic indications of chrysin in various cancers. Online databases comprising Scopus, PubMed, Embase, ProQuest, Science Direct, Web of Science, and the search engine Google Scholar were searched for available and eligible research articles. The search was conducted by using MeSH terms and keywords in title, abstract, and keywords. In conclusion, experimental studies indicated that chrysin could ameliorate cancers of the breast, gastrointestinal tract, liver and hepatocytes, bladder, male and female reproductive systems, choroid, respiratory tract, thyroid, skin, eye, brain, blood cells, leukemia, osteoblast, and lymph. However, more studies are needed to enhance the bioavailability of chrysin and evaluate this agent in clinical trial studies.
\end{abstract}

Keywords: Chrysin, Flavonoids, Oxidative stress, Inflammation, Apoptosis, Metastasis, Proliferation, Transcription factors, Cancer

\section{Introduction}

Cancer is the second leading reason for death universally with an appraised of 606,880 deaths in the United States annually. The American Cancer Society (ACS) estimates that $1,762,450$ new cases of cancer will be detected in the USA just in 2019 [1]. Hence, discover an approach to treat cancer at numerous stages can assist in rescue people's lives. Notably, cancers could be treated by combinations of surgical procedures, radiation therapy, chemotherapy, immunotherapy, and hormone therapy [2]. Meanwhile, chemotherapy is one of the most reasonable cures for

\footnotetext{
*Correspondence: samarghandians1@nums.ac.ir

${ }^{8}$ Noncommunicable Diseases Research Center, Neyshabur University of Medical Sciences, Neyshabur, Iran

Full list of author information is available at the end of the article
}

early- and late-stages. Nevertheless, alopecia, neuropathy, neutropenia, myalgia, nausea, vomiting, diarrhea, fatigue, etc. are the side effects of chemotherapy that lead to less compliance of patients [3]. Flavonoids are considered a versatile source for discovery and development of anticancer agents [4-6]. Chrysin (5,7-dihydroxy2-phenyl-4H-chromene-4-one or 5,7-dihydroxyflavone) is a naturally occurring 15 -carbon backbone-based flavonoid [7]. The most reliable pharmacological properties of chrysin are anticancer, neuroprotective, antiviral, antibacterial, antiasthmatic, anti-inflammatory, hepatoprotective, nephroprotective, cardioprotective, antidiabetic, antidepressant, anxiolytic, and antiarthritic activities [8]. The natural sources of chrysin are honey, where the content of chrysin ranges from $0.10 \mathrm{mg} /$ $\mathrm{kg}$ in honeydew honey to $5.3 \mathrm{mg} / \mathrm{kg}$ in forest honey $[9$,

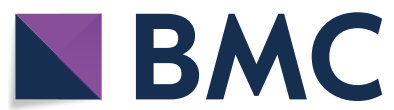

(c) The Author(s) 2021. This article is licensed under a Creative Commons Attribution 4.0 International License, which permits use, sharing, adaptation, distribution and reproduction in any medium or format, as long as you give appropriate credit to the original author(s) and the source, provide a link to the Creative Commons licence, and indicate if changes were made. The images or other third party material in this article are included in the article's Creative Commons licence, unless indicated otherwise in a credit line to the material. If material is not included in the article's Creative Commons licence and your intended use is not permitted by statutory regulation or exceeds the permitted use, you will need to obtain permission directly from the copyright holder. To view a copy of this licence, visit http://creativecommons.org/licenses/by/4.0/. The Creative Commons Public Domain Dedication waiver (http//creativecommons.org/publicdomain/zero/1.0/) applies to the data made available in this article, unless otherwise stated in a credit line to the data. 
10], propolis (chrysin content $28 \mathrm{~g} / \mathrm{L}$ and many plants species e.g. Pelargonium crispum, Passiflora incarnate, Oroxylum indicum, Scutellaria immaculata, Scutellaria baicalensis, Scutellaria ramosissima, Scutellaria discolor, Morinda citrifolia, Docynia delavayi, Dysphania graveolens, Alpiniae oxyphyllae, Desmos cochinchinensis, Cytisus multiflorus, Centaurea omphalotricha, Pleurotus ostreatus, Indigofera tinctoria, Hedyotis diffusa, Achyranthes aspera, Xylopia pierrei, and mushrooms Lactarius deliciosus (chrysin content $\sim 0.17 \mathrm{mg} / \mathrm{kg}$ ), Suillus bellinii (chrysin content $0.34 \mathrm{mg} / \mathrm{kg}$ ), and a marine endophytic strain called Chaetomium globosum [11-26]. In many studies chrysin has been shown to exert beneficial pharmacological activities: it suppressed pro-inflammatory cytokine expression and histamine release, downregulated nuclear factor kappa B (NF-kB), cyclooxygenase 2 (COX-2), and inducible nitric oxide synthase (iNOS) [27], upregulated apoptotic pathways [28], inhibited angiogenesis [29] and metastasis formation [30] protecting from cancer, suppressed DNA topoisomerases [31] and histone deacetylase [32], downregulated tumor necrosis factor $\alpha($ TNF- $\alpha)$ and interleukin $1 \beta$ (IL-1 $\beta$ ) [33], promoted protective signaling pathways in the heart [34], kidney [35] and brain [8], decreased cholesterol level [36], and demonstrated a potent anti-glycemic activity [37]. Regarding these vulnerable potentials of chrysin in the prevention and treatment of physiological disturbances, we reviewed feasible cellular and molecular mechanisms involved in the anticancer impacts of chrysin.

\section{Chemical Properties of chrysin and its derivatives}

Chrysin has two benzene rings (A and $\mathrm{B}$ ) and an oxygencontaining heterocyclic ring (C) in its structure [38]. The antioxidant activity of chrysin is related to the presence of the double bond between $\mathrm{C} 2-\mathrm{C} 3$ and the carbonyl group on the C4 atom [39-41]. Differently, from many flavonoids with $-\mathrm{OH}$ groups on $\mathrm{C} 3$ and $\mathrm{C} 4$ atoms in ring $\mathrm{B}$, chrysin lacks oxygenation in $\mathrm{B}$ and $\mathrm{C}$ rings, and this structural property is linked to the main biological activities of chrysin, ranging from the anti-inflammatory to antitoxic effects $[39,40]$. There are $-\mathrm{OH}$ groups at $\mathrm{C} 5$ and $\mathrm{C} 7$ atoms in chrysin structure, related to the free oxygen radical scavenging activities $[39,40]$. The diversity in the ring-A oxygenation is the principal reason for the formation of numerous natural derivatives of chrysin like baicalein, Oroxylin A, and wogonin [8] (Fig. 1). To enhance the biological activity of chrysin, its various derivatives were synthesized, introducing different substituents in its<smiles>O=c1cc(-c2ccccc2)oc2cc(O)cc(O)c12</smiles>

Chrysin<smiles>COc1c(O)cc2oc(-c3ccccc3)cc(=O)c2c1O</smiles>

Oroxylin A<smiles>COc1c(O)cc(O)c2c(=O)cc(-c3ccccc3)oc12</smiles>

Wagonin<smiles>O=c1cc(-c2ccccc2)oc2cc(O)c(O)c(O)c12</smiles>

Baicalein

Fig. 1 Chrysin chemical structure 
molecule [42]. The introduction of hydrophobic chains at $\mathrm{C} 5$ and $\mathrm{C} 7$ positions improved chrysin's anti-inflammatory activity [43]. The C30, C40-dichloro substituent in the chrysin molecule was responsible for the suppression of prostaglandin (PG) production [44]. Using chrysin backbone following attachment of nitric oxide donor pro-drugs promoted vasculoprotective activity [45] and angiogenesis [46]. Hexadecyl 2-(5-hydroxy-4-oxo-2phenyl- $4 H$-chromene-7-yloxy) acetate and $N$-hexadecyl 2-(5-hydroxy-4-oxo-2-phenyl-4H-chromen-7-yloxy) acetamide were exerted antiproliferative effect [47]. Antitumor activity by 5,7-diacetyl chrysin has been reported in H22 cells in vitro [48]. Diethyl chrysin-7-yl phosphate and tetraethyl bis-phosphoric ester of chrysin were obtained by phosphorylation of $-\mathrm{OH}$ groups at $\mathrm{C} 7$ or both $\mathrm{C} 5$ and $\mathrm{C} 7$ atoms resulting in the enhancement of chrysin antiproliferative properties [49]. Methylation of both $\mathrm{C} 5$ and $\mathrm{C} 7$ resulted in higher effectiveness of this chrysin analog as a feasible chemotherapeutic agent for acute lymphoblastic leukemia [50]. Butyl, octyl, propyl, and tolyl derivatives of the C5- and C7-hydroxyl groups were linked to the anti-glycemic effect deprived of side effects up to $500 \mathrm{mg} / \mathrm{kg}$ [51]. By in silico screening, a series of C7-hydroxyproton substituted chrysin derivatives exhibited EGFR inhibiting possessions against breast cancer [52]. Fluorine-containing chrysin derivatives showed greater antimicrobial and anticancer effects [53].

In a series of chrysin-benzothiazole conjugates using 7-(4-bromobutoxy)-5-hydroxy-2-phenyl-4H-chromene4-one, the presence of halogens, the length of the aliphatic side sequence linking two different pharmacophores as chrysin and benzothiazole, the characteristics and site of the electron-withdrawing and electron-donating functional groups on the benzothiazole backbone were related to the increase in the anticancer activity of chrysin [54] (Fig. 2).

\section{Bioavailability, drug delivery, and toxicity of chrysin} In human organism chrysin is poorly absorbed, rapidly metabolized, and eliminated, therefore its bioavailability is very low [55]. Chrysin is metabolized via conjugation reactions, mainly sulfation and glucuronidation, and less via oxidation in intestinal and hepatic cells [56]. Chrysin sulfonate and glucuronide were existing in the urine and plasma at low concentrations [56], the highest concentrations of chrysin sulfate and glucuronide were observed in the bile in the studies of chrysin metabolism in mice [57], thus the excretion through feces is the main suggested way for the elimination of chrysin and its metabolites [8, $56,57]$. There was reported very low concentrations of this flavonoid in plasma afterward a single $400 \mathrm{mg}$ oral dose of chrysin in humans, the plasma binding was $>99 \%$ [55]. The bioavailability of chrysin in the oral route of administration was appraised to be $0.003-0.02 \%$ [55], the maximum plasma concentration-12-64 $\mathrm{nM}$ [58]. The predicted maximum serum concentration for flavonoid aglycones, generally, is $1 \mathrm{mmol} / \mathrm{L}$ [55], thus the chrysin should be administered to reach the serum concentration in the micromolar range [42]. Drug delivery systems for chrysin using nanoparticles, liposomes, and micelles as carriers have been reported [59-62]. The best approach to overcome the poor bioavailability of chrysin was its encapsulation in nanoparticles [63].

Entrapping chrysin in niosomal oromuco-adhesive films is one of the great strategies to gain a therapeutic

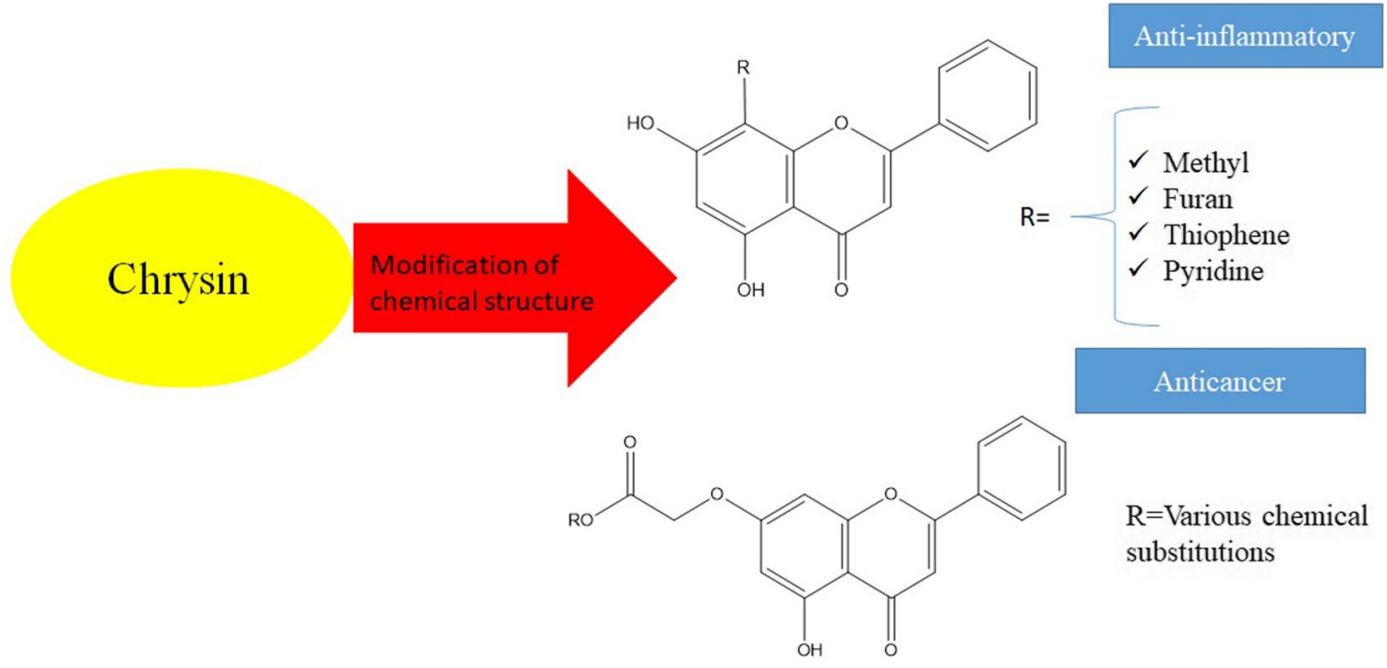

Fig.2 Association of structural modification of chrysin and its substituent pharmacological effects 
drug delivery platform in order to combat oral recurrent aphthous ulcers and enhance the bioavailability of chry$\sin [64]$.

Encapsulation of chrysin in to poly (D, L-lactic-coglycolic acid) poly (ethylene glycol) (PLGA-PEG) nanoparticles controlled the release kinetic of chryisn and its cytotoxicity [65]. It has been found that chrysin/ curcumin loaded in PLGA-PEG reduced the expression of cyclin D1 and the proliferation of breast cancer cells [59]. Moreover, PLGA-PEG nanoparticles endorsed anticancer effects of curcumin/chrysin by attenuation of hTERT gene expression in colorectal cancer SW480 cells and resulted in elevation of bioavailability and the solubility of these naturally-based medications [66]. In addition, chrysin-encapsulated to nanopolymer enhanced the efficacy of chemotherapeutic agents. In this context, previous study indicated that doxorubicin was loaded to PEG-chrysin conjugate nonparticle has more efficacy and safety [67]. It was also found that chrysin delivery with nanostructured lipid carriers (NLCs) increased the efficacy of doxorubicin via decreasing the activity of drug efflux pumps and detoxification enzymes [68]. Doxorubicin loaded mPEG-PCL-chrysin micelles could significantly show potent anticancer activities in vitro, regarding the $\pi-\pi$ stacking interactions among the mentioned micelles and doxorubicin [69]. P(HEMALA-MADQUAT) micelles could assist in co-delivery of methotrexate and chrysin in co-treatment approach in MCF-7 cells [70].

Chrysin has been shown to boost testosterone in humans [71]. The adverse effects have not been reported at the daily dosage of $400-500 \mathrm{mg}$ of chrysin [72]. The suggested amount of chrysin to be consumed daily is considered to be $0.5-3 \mathrm{~g}[8,55,73]$. While low doses of flavonoids are available in the regular dietary intake of individuals, consumption of higher doses may initiate toxicity $[8,73]$. Chrysin has been reported to induce toxicity in trout liver cells and suppression of de novo DNA formation, causing abridged cell numbers [40]. The cytotoxicity due to chrysin has been credited to the possession of peroxidase-like activity in hepatocytes, inducing chrysin's oxidation, consequently making toxic agents. Myeloperoxidase and topoisomerase II also were linked to the toxic effects of chrysin [40], 74.

\section{Literature search methodology}

Online databases comprising Scopus, PubMed, Embase, ProQuest, Science Direct, Web of Science, and the search engine Google Scholar were searched for available and eligible research articles. The search was conducted by using $\mathrm{MeSH}$ terms in title, abstract, and keywords. Obtained results were screened by two independent authors. Studies in English (abstract/full text), original research, with full text available, and showing preventive or therapeutic aspects of chrysin by focusing on involved cellular and molecular mechanisms were included. Data of the literature search was extracted and reported in the current review article (Table 1).

\section{Cellular and molecular mechanisms involved in the therapeutic effects of chrysin \\ Anticancer effects of chrysin \\ Breast cancer}

Breast cancer is an important reason of deaths in women globally [75]. Chrysin pretreatment increased p53 protein expression and diminished viability of MCF7 cells. Pretreatment with chrysin also activated the ATMChk2 pathway without DNA damage [76]. In a previous study coadministration of chrysin and metformin, against T47D breast cancer cells were examined. T47D cells were treated with Metformin, Chrysin, and their combination. Chrysin alone and potentially in combination with metformin decreased cyclin D1 and hTERT gene expression in the T47D breast cancer cell line [77, 78]. In a study of the MCF-7 cell line, induction of cell apoptosis was obtained by chrysin pretreatment [79]. Yang et al. utilized metastatic triple-negative breast cancer (TNBC) cell lines to investigate the antimetastatic effect of chrysin. Chrysin pretreatment inhibited MMP10 and Akt signaling pathways [80]. Lirdprapamongkol and coworkers studied on 4T1 murine mammary carcinoma cell line in hypoxic conditions and xenografts. Chrysin declined hypoxic survival, inhibited activation of STAT3, and reduced VEGF expression in hypoxic cancer cells, causing annulment of hypoxia-induced angiogenesis and occasioning suppression of metastatic growth [30]. Chrysin ameliorated TRAIL-mediated apoptosis in MDA-MB-231 [81]. Hepatic microsomes from Nile tilapia (Oreochromis niloticus) were investigated. Chrysin inhibited the MCF-7 cancer cells proliferation and also it had powerful anti-aromatase activity [82]. MDAMB-231 cells were utilized for the evaluation of chrysin effects. Chrysin induced apoptosis via inducing Skp2 and LRP6 expressions. Chrysin pretreatment also downregulated MMP2, MMP9, fibronectin, and snail expression. The mRNA expression of PPAR $\alpha$ noticeably increased in chrysin-treated MDA-MB-231 cells, which was feasibly related to the anti-proliferative effects of chrysin $[17,83]$. The capability of an analog of chrysin to inhibit EGFR was reported in a breast cancer stem cell model [84]. A novel chrysin-organotin (Chrysin-Sn) compound considerably elevated ROS levels in MCF-7 cells and regarding apoptosis activated caspase- 3 and prompted autophagy through augmentation of LC3-II level [85]. Chrysinruthenium complex modulated mTOR, VEGF, and p53 signaling pathways in the MCF-7 cells [86]. Pretreatment 
Table 1 Some of the molecular and cellular mechanisms involved in preventive and therapeutic indications of chrysin

\begin{tabular}{|c|c|c|}
\hline Health effect & Mechanisms & Refs. \\
\hline Breast cancer & Antiproliferative effect & [79] \\
\hline Breast cancer & Downregulated cyclin D1 and hTERT & [78] \\
\hline Breast cancer Stem cell & Inhibited EGFR & [84] \\
\hline Breast cancer & Apoptosis & [85] \\
\hline Breast cancer & Apoptosis & [80] \\
\hline Breast cancer & $\begin{array}{l}\text { Inhibited angiogenesis, alleviated VEGF expression, Suppressed metastatic growth due to alleviation of } \\
\text { activation of STAT3 and hypoxic survival }\end{array}$ & [30] \\
\hline Breast cancer & Inhibited of HDAC8 enzymatic activity & [213] \\
\hline Breast cancer & modulated phase I and phase II enzymes & [214] \\
\hline Gastric cancer & Altered microRNAs expression & [94] \\
\hline Gastric cancer & Blocked AP-1 and suppressed early growth response-1 & {$[98,99]$} \\
\hline Buccal pouch carcinoma & mitigated phase-I enzymes (Cyt b5 and Cyt p 450) and increased phase-II enzymes (GSH, GST, GR, and DTD) & [215] \\
\hline Colon cancer & Arrested G2/M phase of cell cycle & [112] \\
\hline Colorectal cancer & Inhibited cell proliferation, improved antioxidant mineral levels, reduced nitrosative stress & [216] \\
\hline Colon cancer & Modulated cryptal cell proliferation activity inhibited apoptosis & [217] \\
\hline Hepatocellular carcinoma & Overexpressed hexokinase-2 & [129] \\
\hline Hepatocellular carcinoma & $\begin{array}{l}\text { attenuated NF-kB p65 levels and COX-2 expression, reduced Bax, Bcl-xL, } \beta \text {-arrestin-2, caspase-3, and p53 } \\
\text { regarding apoptosis }\end{array}$ & [136] \\
\hline Hepatocellular carcinoma & Attenuated the canonical Wnt and NF-kB, induced apoptosis & [140] \\
\hline Liver cancer & Downregulated the $\beta$-catenin expression & [218] \\
\hline Renal carcinoma & Ameliorated oxidative stress, hyperproliferation, and inflammation through NF-kB pathway & [143] \\
\hline Skin cancer & Attenuated the MSK1/histone $\mathrm{H} 3$ signaling & [219] \\
\hline Skin cancer & Inhibited tumor growth and neoplastic transformation by targeting CDK2 and CDK4 & [220] \\
\hline Melanoma & mitigated the TERT, MMP-2, and MMP-9 genes levels, ameliorated genes expressions of TIMP-1 and TIMP-2 & [192] \\
\hline Anaplastic thyroid carcinoma & Induced apoptosis by activating Notch1 signaling related to PARP cleavage & [180] \\
\hline Prostate cancer & Inhibited expression of HIF-1a via Akt signaling pathway and abrogated VEGF expression & [153] \\
\hline Prostate cancer & Inhibited DNA methyltransferases & [221] \\
\hline Leukemia & $\begin{array}{l}\text { Enhanced populations of T-and B cells (CD-3, CD-19, and Mac-3), Promoted macrophage phagocytosis and } \\
\text { NK cell cytotoxicity }\end{array}$ & [202] \\
\hline Leukemia & reduced cell viability and induced DNA fragmentation regarding apoptotic cell death & {$[222]$} \\
\hline Leukemia & $\begin{array}{l}\text { Induced apoptosis in } \mathrm{BCl}-2 \text { overexpressing associated with PLC- } 1 \text { 1 degradation, caspase-3 activation, XIAP } \\
\text { downregulation, and the Akt inactivation }\end{array}$ & {$[205,223]$} \\
\hline Leukemia & attenuated SCF/c-Kit signaling by abrogation of PI3K pathway & [204] \\
\hline Cervical cancer & inhibited proliferation and induced apoptosis & [49] \\
\hline Cervical cancer & induced p38 and NF-kB/p65 activation & [224] \\
\hline Cervical cancer & Increased caspases-3 and -9, Bax, and cleaved-PARP expression, caused arrest in G2 phase of cell cycle & {$[22]$} \\
\hline Cervical and ovarian cancer & Antioxidant and anticancer & [54] \\
\hline Ovarian cancer & Antioxidant and anticancer & [225] \\
\hline NSCLC & Inhibited IL-6-induced AKR1C1/1C2 overexpression & {$[176]$} \\
\hline Glioma & Antiproliferative and apoptotic activity & [194] \\
\hline Glioma & Increased accumulation of arsenic & [226] \\
\hline Ehrlich ascites & Enhanced functional activity of macrophages & [212] \\
\hline
\end{tabular}

with chrysin remarkably suppressed TNBC cell migration and invasion. chrysin downregulated MMP-10, reduced snail, slug, and vimentin expressions increased E-cadherin expression, and inhibited Akt signaling pathway in TNBC cells, proposing that chrysin possessed a reversal activity on EMT [80]. Zhang and coworkers found that pretreating MCF-7 cells with chrysin caused BCRP inhibition, which was resulted in significant increases in mitoxantrone accumulation [87]. 8-bromo7-methoxychrysin, a synthetic analog of chrysin exhibited anticancer properties via downregulation of CDK4, cyclin D1, and cyclin E, inactivation of Akt, GSK-3 $\beta$ and 
$\beta$-catenin in HER-2/neu-overexpressing MDA-MB-453 and BT-474 cells [88]. Zhao and coworkers found that 5,7-dihydroxy-8-nitrochrysin could stimulate cell fate in MDA-MB-453 cells via activation of caspase and modulation of the Akt/FOXO3a pathway [89]. By substitution of benzyloxy, dimethylamino, nitro, and fluoro on chrysin structure, potent cytotoxic agents were synthetized that displayed considerable cytotoxicity against MDAMB-231 and MCF-7 [90].

Fabrication of chrysin-attached to silver and gold nanoparticles crossbred reduced graphene oxide nanocomposites led to augmentation of the generation of ROS-induced apoptosis in breast cancer [91]. Chrysin loaded PCL-PEG-PCL had greater antitumor impact on gene expression of BRCA1, FTO, and hTERT in comparison to free chrysin [92].

\section{Gastric cancer}

Gastric cancer is considered as the third important reason of cancer-related deaths globally. Various etiologies have participated in the initializations and progressions of gastric cancer including gene-environment dealings with Helicobacter pylori as the most prevailing reasons for the pathogenesis of gastric cancer, numerous genetic and epigenetic changes have been connected with its carcinogenesis moreover. The human gastric epithelial cell line (GES-1) and human gastric cancer cell lines (MKN45) and Nude Mice Xenograft Model were studied. Evaluation of Ten-eleven translocation (TET) 1 expression via qRT-PCR following chrysin consumption was assessed. Chrysin induced augmentation in TET1 (responsible for cell apoptosis, migration, and invasion) expression via enhancement of $5 \mathrm{hmC}$ levels and exerted cytotoxic effects in MKN-45 cells. Chrysin-treatment caused inhibition of cell migration and attenuation of invasion in MKN-45 cells. Cell apoptosis (Bax and Bcl2) and cell cycle altered by G0/G1 arrest and decline in the number of cells in the $\mathrm{S}$ phase. From in vivo findings, it was concluded that chrysin reduced tumor growth and promoted TET1 expression. CRISPR/Cas9 system was used to generate the TET1 gene knocked out. Collectively, the study directed that chrysin displayed anti-tumor properties through regulating TET1 expression [93]. In another study, it has been observed that chrysin downregulated miR-18, miR-21, and miR-221 expression however upregulated let-7a, miR-9, miR-22, miR-34a, and miR-126 expression in the gastric carcinoma cell line [94]. Higher elevation of miR-22, miR-34a, miR-126, miR-9 and Let$7 \mathrm{a}$ gene expression was observed in the case of utilization of chrysin-PLGA-PEG nanoparticles, in comparison with free chrysin $[95,96]$. Higher downregulation of miR-18a, miR-21 and miR-221 genes was obtained by chrysinloaded PLGA-PEG nanoparticles [97]. The AGS human gastric cancer cell line was utilized in a study. Chrysin controlled MMP-9 expression via suppression of AP-1 activity which blocked ERK1/2 and JNK1/2 signaling pathways in gastric cancer AGS cells [98]. Chrysin significantly inhibited endogenous and inducible Recepteur d'origine Nantais (RON) expression. Chrysin inhibited Egr-1 and NF- $\mathrm{kB}$ transcription factor activities in AGS [99]. Bakhsheshian and coworkers demonstrated that chrysin inhibited Pp-18 efflux in both human and mouse ABCG2 [100]. A chrysin benzimidazole derivative could arrest the G0/G1 phase of the cell cycle in MFC cells [101]. Ai and coworkers used SGC-7901 cells to evaluate the efficacy of 5, 7-dihydroxy-8-nitrochrysin (NOChR). NOChR induced apoptosis of SGC-7901 cell lines by activation of PPAR $\gamma$ and reduction of the Bcl-2/Bax ratio [102]. Chrysin overcomed the 5-FU-resistance in gastric cancer AGS and AGS/FR cells via $S$ phase arrest [103]. 8-Bromo-7-methoxychrysin induced apoptotic cell fate in SGC-7901 cell line partly by motivating PPAR $\gamma$ [104]. 7-O-carboxymethyl chrysin exhibited greater apoptotic and anti-proliferative effects on human gastric carcinoma MGC-803 cells [105].

\section{Colorectal cancer}

Colorectal cancer is one of the most globally common types of cancers with continuously increased incidence each year [106]. Chrysin meaningfully amplified LC3II levels, an autophagy-associated marker, in colorectal cancer cells. Pretreatment with chrysin induced ROS formation, and consecutively, inhibited Akt phosphorylation and mTOR. In accumulation, the reported findings suggested that chrysin might be a potential candidate through autophagy which can be replaced 5-FU and oxaliplatin combination combat colorectal tumors for colorectal cancer management in the coming [107]. In earlier research, it has been revealed that AHR was mandatory for the apoptosis inducting following pretreatment with chrysin. The augmentation of TNF- $\alpha$ and TNF- $\beta$ gene expression in human colorectal cancer cells were found [108]. In vivo transplanted CT26 tumor cells in mice and in vitro CT26 cells were investigated. Chrysin reduced tumor volume via the upregulation of the Bax and downregulation of the sall4 [109]. Chrysin ameliorated TRAIL-mediated apoptosis in HT-29 and HCT-116 cell lines $[28,81]$. Human colon carcinoma cells (Caco-2) were utilized by Schumacher and coworkers. Pretreating cells with chrysin inhibited P-gp, MRP-2, and BCRP. Moreover, chrysin augmented $\mathrm{ABC}$-transporters expression in Caco- 2 cells [110]. Romier et al. found that chrysin intensely abridged IL- $1 \beta$-induced IkB- $\alpha$ phosphorylation, diminished IL-8 secretion, and blocked NF-kB activation via the inhibition of IkB- $\alpha$ phosphorylation [111]. The pretreatment of HT-29 with chrysin oxidovanadium 
(IV) complex evoked cell cycle arrest in the G2/M phase [112]. Effects of chrysin on HCT116 colon adenocarcinoma cell lines were studied. Chrysin inhibited mRNA expression of PPAR $\alpha$, significantly increased cell population of the G0/G1 phase, and declined the proportion in $\mathrm{S}$ phase. Hence chrysin regulated the migration activity and the expression of CYP1B1 and CYP2S1 in colorectal cancer cells [113]. Galijatovic et al. found that chrysin pretreatment increased UGT1AI expression in Caco-2 cells [114]. Encountering of HCT-116 cells with chrysin resulted in DNA damage and prompted mitochondrial membrane agitation go along with downregulation of $\mathrm{Bcl}-2$, activation of BID and Bax, cytochrome c release, and caspase-3-mediated apoptosis. Regarding the aforementioned findings, ROS production by chrysin was the critical mediator behind induction of ER stress, leading to JNK phosphorylation, intracellular $\mathrm{Ca}^{2+}$ release, and activation of the mitochondrial apoptosis pathway [115].

Salama et al. discovered that anticancer activity of chrysin against SW620 cells were connected with reduced protein expression of p-ERK/ERK and p-Akt/Akt [116]. Ren and coworkers found that 7-piperazinethylchrysin alleviated mitochondrial membrane potential of HCT116 cells and augmented the generation of intracellular ROS. In addition, elevation of Bax and reduction of $\mathrm{Bcl}-2$ at protein expression levels were observed. Activation of p53, caspase-3 and -9 , release of cytochrome c, PARP1 cleavage, and downregulation of $\mathrm{p}$-Akt were other alterations following the use of 7-piperazinethylchrysin [117].

\section{Esophageal carcinoma}

Squamous cell carcinoma and esophageal malignancies are the two main types of esophageal cancer, with distinct etiological and pathological features. Two reports indicated that chrysin exhibited cytotoxicity in human esophageal squamous cell carcinoma cell lines (KYSE510) and (OE33). It was observed that the treatment of KYSE-510 and OE33 cells with chrysin inhibited the G2/M cycle via the up-regulation of P21 and GADD45beta and down-regulation of cyclin B1 at the mRNA and protein levels. Besides, chrysin induced p53-independent mitochondrial-mediated apoptosis via up-regulation of PIG3 and cleavage of caspase-9 and -3 [118-120]. Downregulation of cyclin B1 and cyclin D1 and upregulation of $14-3-3 \sigma$ at the mRNA and protein levels which were related to the proliferation and differentiation of cells were witnessed afterward the treatment of OE33 cells with chrysin $[121,122]$.

\section{Tongue cancer}

The squamous cell carcinoma (SCC) is frequently observed in the oral cavity that is highly invasive with high lymph nodes metastases. It was found that proline metabolism and proline dehydrogenase/proline oxidase (PRODH/POX) has the main role in the modulation of cancer cell survival/apoptosis. To assess the effect of chrysin on the cytotoxicity, proliferation, expression of apoptotic protein and proline metabolism and concentration in SCC, the MTT, proliferation and western blot assays and also HPLC were used, respectively. Chrysin could stimulate anti-proliferative activity, as well as the expression of PRODH/POX, P53, caspases-3 and -9 and reduced collagen biosynthesis, prolidase activity, and proline concentration in human tongue squamous cell carcinoma (CAL-27) cells. Indeed, chrysin induced PRODH/POX-dependent apoptosis via an increase in the degradation of mitochondrial proline and a decrease in proline content for collagen biosynthesis [123]. Xie and colleagues demonstrated that chrysin had apoptotic effects on KB cells which might be associated to mitochondrial dysfunction and hindering of PI3K/Akt cascade [124].

\section{Hepatocellular carcinoma}

Hepatocellular carcinoma is one of the most communal gastrointestinal system malignancies, place as the fifth fatal cause of cancers universal [125]. SMMC-7721 and MHCC97H cells were evaluated for the determination of chrysin potential to combat hepatocellular carcinoma. Chrysin meaningfully inhibited sphere formation and upregulated SHP-1 protein expression in SMMC7721 and MHCC97H cells, besides abridged p-STAT3 and Twist1 expressions in SMMC-7721 cells. collectively, it has appeared that chrysin acted as a nominee against HCC via regulating the SHP-1/STAT3 signaling pathway [126]. Sorafenib is a multikinase inhibitor as a proven treatment for progressive HCC. Conversely, its therapeutic efficacy is not as worthy as was expected. Therefore, improvement sensitivity of HCC to sorafenib would be effective. A previous study verified that coadministration of chrysin improved sorafenib sensitivity through inhibition of ATP-binding cassette superfamily $G$ member 2 (ABCG2). Hep3B and HepG2 HCC cells were assessed. Chrysin prompted sustained ERK1/2 phosphorylation and promoted overexpression of mitogen-activated protein kinase 1 (MEK1). These findings displayed the ERK1/2 phosphorylation mechanism contributing a chrysin-mediated synergistic effect on sorafenib sensitivity in HCC cells [127]. In another study, 2-acetylaminofluorene (2-AAF) and diethylnitrosamine (DEN) were used for the induction of HCC in rats. Chrysin pretreatment led to an increase in mitochondrial ROS creation, swelling in isolated mitochondria from hepatocytes, collapse in MMP, and release cytochrome $c$. Furthermore, Chrysin could elevate caspase- 3 activity in the HCC rats group. From these findings, chrysin could be considered as a talented 
complementary therapeutic candidate combat HCC, but further preclinical and clinical trials are needed [128]. In a previous study of HCC cells and xenograft models, chrysin declined HK-2 combined with VDAC-1 on mitochondria, resulted in the transformation of Bax to mitochondria and induced cell apoptosis [129]. The effects of chrysin in human HCC, QGY7701, and HepG2 cells were evaluated in a recent study. Chrysin encountering improved proapoptotic protein expression, containing Bax, Bad, Bak, and p53 whereas it reduced Bcl-2. It was revealed that chrysin motivated programmed cell death in the $\mathrm{HCC}$ cells by modulating the $\mathrm{p} 53 / \mathrm{Bcl}-2 /$ caspase- 9 signaling pathway $[130,131]$. Chrysin arrested the SubG0 phase of the cell cycle in HepG2 cells [132]. Chrysin ameliorated TRAIL-mediated apoptosis in HepG2 [81]. Gao et al. elucidated that a higher level of Nrf2 expressed in BEL-7402/ADM cells associated with doxorubicin resistance, and chrysin inhibited the Nrf2 expression and its downstream genes comprising AKR1B10, HO-1, and MRP5 by quenching ERK and PI3K-Akt pathway and ultimately resulted in a reversal of drug-resistant phenotype [133, 134]. H22 ascitic hepatoma cells and xenograft mice were exposed to chrysin. Chrysin activated caspase-3 regarding apoptosis, but also inhibited the generation of VEGF and suppressed angiogenesis [11]. Hepatic microsomes from Nile tilapia (Oreochromis niloticus) were investigated. Chrysin inhibited the proliferation of HepG2 cancer cells and also it had powerful anti-aromatase activity [82]. Huang et al. demonstrated that, chrysin induced apoptosis via inducing Skp2 and LRP6 expressions. Chrysin pretreatment also downregulated MMP2, MMP9, fibronectin, and snail expression [17]. Sun et al. demonstrated that chrysin induced GRP78 overexpression, spliced XBP-1, and eIF2- $\alpha$ phosphorylation. Besides, Chrysin persuaded caspase-7 cleavage and PARP cleavage [135]. Khan and coworkers revealed the effectiveness of chrysin in DEN-induced early hepatocarcinogenesis in rats. Chrysin administration significantly reduced AST, ALT, ALP, LDH and $\gamma$ GT serum activities. Moreover, chrysin attenuated COX-2 and NFkB p65 expression, and $\mathrm{Bcl}-\mathrm{xL}$ and $\beta$-arrestin levels, whereas that of p53, Bax and caspase 3 increased at the mRNA and protein levels [136]. Walle et al. revealed that chrysin induced UDP-glucuronosyltransferase UGT1A1 in HepG2 cells [137]. Sherif et al. discovered that chrysin could combat hepatocellular carinoma through the inhibition of the GPC3/SULF2 axis accompanied by the downregulation of IncRNA-AF085935 expression [138]. Wang and collegues found that chrysin nanosuspension had higher anti-tumor effects against human HepG2 cells [139]. Administration of methylated chrysin in the early hepatocarcinogenesis rat model resulted in attenuation of Wnt and NF-kB pathways [140]. Yang et al. observed that 8-bromo-7-methoxychrysin could induce apoptosis of HepG2, Bel-7402 and L-02 cells by generation of ROS and sustained activation of JNK [141].

\section{Renal cell carcinoma}

Renal cell carcinoma (RCC) is one of the most common malignancies in adults' kidneys. RCC is regularly resistant to conventional chemotherapeutic regimens. A rat model of renal cancer was initiated by DEN and promoted by ferric nitrilotriacetate (Fe-NTA). Administration of chrysin alleviated LPO and promoted CAT, GSH, GR, and GPx activities. Moreover, chrysin diminished BUN and creatinine. Reduction in IL- 6 and TNF- $\alpha$ and augmentation in caspases- 9 and 3 were observed due to chrysin supplementation. Chrysin induced entire suppression NF-kB, COX-2, PG-E2, iNOS as well. Downregulation of PCNA, ODC and $\mathrm{Bcl}-2$ vice versa upregulation of Bax proteins have resulted in chrysin supplementation $[142,143]$.

\section{Bladder cancer}

Bladder cancer is the second most communal type of 'tract cancer' in developed countries.

One study investigated the effect of chrysin on apoptosis, ROS production and DNA fragmentation by using western blot and flow cytometer techniques. Chrysin provoked apoptosis due to activation of caspases- 3 and 9, reduced Bcl-2, Mcl-1, Bcl-xl expression, and promoted Bax protein expression. Chrysin also persuaded ER stress via activation of the unfolded protein response of PRKR-like ERK, eIF2 $\alpha$, and activating transcription factor 4 in bladder cancer cells, and inhibited the signal transducer and activator of the transcription 3 pathway. Furthermore, the alleviation of ROS generation was detected following treatment with chrysin [144]. The results suggested that chrysin was effective against bladder cancer through increasing apoptosis and ROS production. One of the main markers indicated the poor prognosis in patients with urinary bladder tumor that is mutation in tumor protein p53 (TP53) gene. It was found that the progression of bladder tumor cell was inhibited by chrysin at doses $10-100 \mu \mathrm{M}$ in mutated and wild type TP53 in grade 1-3. Cell proliferation inhibition by chrsin was confirmed by elevation in reactive oxygen species (ROS) production and decrease in DNA damage. Chrysin could affect cell cycle at G2 and M phases and cell morphology following decrease in the expression of PLK1, HOXB3 and SRC genes in mutated TP53 cells,. Chrysin also stimulated in DNA hypermethylation grade 2 cells, and decreased the expression of c-MYC, FGFR3 and mTOR gene in grade 3 cells. The authors suggested that the anti-proliferative effect of chrysin was not dependent to TP53 status in bladder tumor cells; but, the involved 
mechanisms are associated with TP53 status $[145,146]$. Szliszka and coworkers observed that combination-therapy of bladder cancer cells with TRAIL and chrysin led to higher sensitization of bladder cancer cells to TRAIL prompted cytotoxicity $[147,148]$.

\section{Prostate cancer}

Prostate cancer is a frequently diagnosed cancer in men worldwide [149]. Prostate cancer (DU145 and PC-3) cell lines were used to assess the role of chrysin in prostate cancer. Chrysin induced apoptosis of cells by causing DNA fragmentation and increasing the proportions of DU145 and PC-3 cells in the sub-G1 phase of the cell cycle. Additionally, chrysin abridged the expression of proliferating cell nuclear antigen in the DU145 and PC-3 cell lines. Likewise, chrysin induced loss of mitochondria membrane potential, while augmented lipid peroxidation and ROS production. Also, it induced ER stress via activation of UPR proteins comprising PERK, eIF2 $\alpha$, and GRP78 in DU145 and PC-3 cells. The chrysin-mediated intracellular signaling pathways suppressed PI3K and the abundance of AKT, S6, P70S6K, and P90RSK proteins, but motivated MAPK and activation of P38 and ERK1/2 proteins in the prostate cancer cells [150-152]. $\mathrm{Fu}$ and coworkers utilized DU145 cells and DU145 xenograft-induced angiogenesis in nude mice. Chrysin inhibited insulin-induced expression of (hypoxia-inducible factor- $1 \alpha$ ) HIF- $1 \alpha$ by decreasing its stability. Chrysin increased the ubiquitination and degradation of HIF- $1 \alpha$ by increasing its prolyl hydroxylation. Furthermore, chrysin hindered with the interaction between HIF-1 $\alpha$ and heat shock protein 90. Chrysin abrogated HIF-1 $\alpha$ expression through AKT signaling, which led to the suppression of VEGF expression [153]. Szliszka and coworkers elucidated the higher sensitization of LNCaP cells through upregulation of TRAIL-R2 following the chrysin pretreatment [154].

\section{Ovarian cancer}

Coadministration of TNF- $\alpha$ and TGF- $\beta$ with or without the presence of chrysin was studied in OVCAR-3 cells. For this reason, proliferation assays (using a cell proliferation enzyme-linked immunosorbent assay (ELISA) 5-bromo-2'-deoxyuridine (BrdU) kit), immunofluorescence microscopy (the expression of proliferating cell nuclear antigen (PCNA), flow cytometer (ROS production), mitochondrial staining kit (mitochondrial membrane potential) and Western blot analysis (protein expression) were used. Chrysin inhibited a pro-inflammatory cytokine to induce EMT and CSLC features in OVCAR-3 cells, which may be convoluted in hindering the NF- $\mathrm{kB} /$ Twist axis [155]. Chrysin's role in the progression of (ES2 and OV90) ovarian cancer cell lines was studied. Chrysin pretreatment increased ROS formation, cytoplasmic $\mathrm{Ca}(2+)$ levels, and diminished mitochondrial membrane potential (MMP). Furthermore, the chrysin activated MAPK and PI3K/AKT pathway $[156,157]$. Chrysin inhibited the sphere formation ability of SKOV3-derived ovarian cancer stem-like cells through downregulation of CK2 $\alpha$ protein expression [158]. 8-bromo-7-methoxychrysin led to cell fate in cisplatin-sensitive/resistant A2780 and A2780/DDP cells happened via the regulation of Akt/FOXO3a, resulting in transcription of Bim [159]. Selenium-chrysin polyurea dendrimer nanoformulation increased GSH depletion cystathionine $\beta$-synthase inhibition in ES2, OVCAR3, and OVCAR8 cell lines [160]. 5-Allyl-7-Gen-Difluoromethylenechrysin induced apoptosis in $\mathrm{CoC} 1$ cells by activation of PPAR $\gamma$ accompanied by alleviation of protein levels of NF- $\mathrm{kB}$ and Bcl-2 and augmentation of Bax expression [161].

\section{Cervical carcinoma}

Cervical carcinoma can be induced following chronic infection with high-risk human papillomavirus (HPV) and is one of the reasons for fatal malignancies [162, 163]. HeLa cell line was studied to investigate the effects of chrysin co-administered by TNF- $\alpha$ and TGF- $\beta$. HeLa cells were exposed to TNF- $\alpha$ and TGF- $\beta$ for one day after TGF- $\beta$ alone for $6 \mathrm{~d}$ with or whit out chrysin at 5.0, 10.0 and $20.0 \mu \mathrm{M}$ concentrations. The levels of EMT-associated parameters, transcription factors, and stem cell indices were assessed using immunoblot. The migration and self-renewal capabilities of cells were evaluated by wound healing and tumor sphere assays. The findings indicated that chrysin was effective in HeLa cell by inhibiting EMT and CSLC properties, NF-kBp65, and Twist1 expression [164].

\section{Choriocarcinoma}

Choriocarcinomas commonly progress by hydatidiform mole identified as overgrowth of tissue from the placenta or an abnormally fertilized egg, which is often observed in pregnant women. Choriocarcinomas possess the capability to metastasize quickly via a hematogenous route. Choriocarcinomas are commonly resistant to treatment and delayed diagnosis will make the curing process harder [165]. Inhibitory effects of chrysin on human choriocarcinoma cells (JAR and JEG3) was investigated by using proliferation assay (using the ELISA, BrdU kit), immunofluorescence microscopy (the expression of PCNA). FITC Annexin V apoptosis detection kit I, lipid peroxidation assay, mitochondrial staining kit (changes in the JC-1 mitochondrial membrane potential), Cytosolic calcium ion concentration assay and Western blot analysis (protein expression). Chrysin disrupted intracellular 
homeostasis by altering MMP, cytosolic $\mathrm{Ca}(2+)$ levels, ROS generation, and lipid peroxidation, which plays a role in the death of choriocarcinoma cells. As well as chrysin mediated the regulation of the AKT, ERK1/2, and JNK signaling pathways [166, 167]. Chrysin decreased $3 \mathrm{H}$-2-deoxy-D-glucose apical uptake in human choriocarcinoma (BeWo) cells [168].

\section{Lung cancer}

Lung cancer is one of the causing reasons of carcinomaconnected fates [169]. The irregular expression of claudins (CLDNs), is observed in several solid tumors. CLDN1 and CLDN11 are significantly expressed in human lung squamous cell carcinoma (SCC). Chrysin decreased CLDN1 and CLDN11 expression in human lung SCC (RERF-LC-AI) cells. Chrysin alleviated p-Akt and inhibited PDK1 and Akt [170]. $\mathrm{NiCl} 2(\mathrm{Ni})$ induced migration and invasion in A549 and H1975 human lung cancer cells. Chrysin inhibited cytokines release, TNF$\alpha$, IL-1 $\beta$, IL-10, and IL-6 induced by Ni in A549 cells. Chrysin suppressed TLR4 and Myd88 mRNA and protein expression. Furthermore, chrysin also decreased the nuclear level of p65 (NF- $\mathrm{kB}$ ), the phosphorylation of ІкB, and IKK $\beta$, besides the MMP-9 expression in A549 cells exposed to $\mathrm{Ni}$ [171]. In a study of A549 cells conducted by Samarghandian and coworkers, chrysin increased Bax protein expression vice versa decreased $\mathrm{Bcl}-2$ protein expression. Moreover, chrysin elevated caspase- 3 and -9 activation confirmed the apoptotic role of chrysin on A549 cells [172]. Benzo (a) pyrene [B(a)P] induced lung carcinogenesis in mice was studied. Chrysin treatment mitigated lipid peroxidation and carcinoembryonic antigen and augmented CAT, SOD, GPx, GSH, GST, vitamin E, and vitamin C. Chrysin downregulated PCNA, COX2 , and NF- $\mathrm{kB}$ proteins expression [173]. In another study, chrysin activated AMPK in A549 cells [174]. Coadministration of chrysin and doxorubicin-induced apoptosis in A549 cells, H157, H1975, and H460 cells via modulation of MRP1, MRP3, and MRP5 expression and total GSH efflux [175]. Wang et al. demonstrated that chrysin could be used as a potential adjuvant therapy for drug-resistant NSCLC, especially for those with AKR1C1/1C2 overexpression [176]. 7-piperazine ethyl chrysin inhibited the viability of A-427 and A-549 lung cancer cells via suppression of ERK1/2 expression [169].

\section{Pulmonary mucoepidermoid carcinoma}

Mucoepidermoid carcinoma is the most frequent form of minor salivary gland malignancy in adults. Mucus secretion in the airway is a very main defense against microbial and chemical pollutants. Any abnormality in the production and secretion of mucins causes a pathological condition in the airway such as mucoepidermoid carcinoma.
The effect of chrysin on NCI-H292 cells induced by PMA and EGF were evaluated by measuring MUC5AC mucin gene expression and mucin protein generation using rtPCR and ELISA assay. It was found that chrysin inhibited MUC5AC mucin generation and gene expression in a human pulmonary mucoepidermoid carcinoma cell line (NCI-H292) which is exposed to phorbol 12-myristate 13-acetate (PMA) or epidermal growth factor (EGF). The study found that chrysin inhibited the expression of mucin gene and mucin protein generation by direct effect on airway epithelial cells [177].

\section{Anaplastic thyroid cancer}

Anaplastic thyroid cancer (ATC) is a very aggressive thyroid gland malignancy with a very underprivileged prognosis $[178,179]$. The effect of chrysin as a Notch activator was evaluated on ATC both in vitro and in vivo. Chrysin treatment upregulated mRNA levels of Notch1 and Hes1 (hairy/enhancer of split 1), a downstream Notch1 effector. Activation of Notch1 in vivo was related to the induction of cleaved PARP protein, representing that the growth inhibition was attributable to apoptotic cell death. Chrysin inhibited tumor growth in ATC both in vitro and in vivo through inducing Notch1 [180]. Chrysin inhibited growth and induced programmed cell death of ATC cells. Indeed, chrysin pretreatment led to Notch-1 activation and SLUG inactivation [181]. Phan and coworkers investigated the effects of chrysin on ATC (HTH7 and KAT18) cells. Cell proliferation was assessed each $48 \mathrm{~h}$ using MTT assay and western blot analysis was used for molecular indices of apoptosis. Pretreating cells with chrysin increased cleaved PARP, cleaved caspase-3, and declined cyclin D1, Mcl-1, and XIAP. Also, expression of the Bax/Bcl-2 ratio in ATC cells was augmented after chrysin exposure. The results suggested that chrysin was suitable for clinical for treating patients with ATC [182]. Wei et al. found that iodo-chrysin derivatives had higher anti-tumor effects on SW-579 and TT cell lines [183].

\section{Nasopharyngeal carcinoma}

Nasopharyngeal carcinoma (NPC) is the most frequent tumor in the nasopharynx in children and adults. Tumor necrosis factor (TNF)-related apoptosis-inducing ligand (TRAIL) belongs to the TNF family that can stimulate apoptosis in various cancer cells including NPC cells without affecting the human healthy cells. Pre-treatment of human cancer cell lines with chrysin induced cell death through stimulating TRAIL, as evidenced by the morphological alterations and present of sub-G1 peak. In HCT-116 cells, flow cytometry indicated that the percentage of sub-G1 increased with chrysin. It was observed that pretreatment with chrysin increased TRAIL-degraded caspase 3, caspase 8, and PARP 
proteins in human nasopharyngeal (CNE1 and -2) cells. Collectively, chrysin could stimulate apoptosis induced by TRAIL, and apoptosis is associated with caspase 8 activation $[28,184]$.

\section{Melanoma}

Melanoma is the most fatal skin cancer with poor prognosis and the global incidence of melanoma has increased in the recent 20 years $[185,186]$. Human melanoma cancer A375.S2 cells were assessed regarding chrysin antimetastasis effects. Chrysin inhibited migration and invasion of A375.S2 cells that were examined by wound healing and the Transwell filter. Chrysin inhibited p-AKT (Thr308), PKC, GRB2, SOS-1, NF-kBp50, and NF-kBp65 expression, decreased Ras, PI3K, Snail, and p-c-Jun, p-AKT(Ser473), uPA, N-cadherin and VEGF, MMP-1, and MMP-2 [187]. In vitro and in vivo analysis were conducted by B16F10 cells and mice received B16F10. Chrysin administration inhibited cancer cell growth by inducing apoptosis and cell cycle arrest at the G2/M phase. Besides, chrysin treatment augmented the cytotoxic doings of CTL, NK, and macrophages [188]. A375 cells were used and chrysin showed in vitro anticancer activity that is allied with possible conscription of STAT-1, 3, 5 proteins at STAT ( -692 to -684 ) region of p21 promoter and the induction of histone hyperacetylation. These findings also supported a surprising impact of chrysin on the chromatin organization of p21WAF1 promoter via hyper-acetylation and histone methylation [189]. Chrysin ameliorated TRAIL-mediated apoptosis in the SK-MEL-37 cell line [81]. Mouse melanoma cell line (B16-F1) and A375 cell lines were studied by Pichichero and coworkers. Pretreating cell lines with chrysin increased PBG-D expression. Besides, it increased caspase- 3 and Bax and downregulated ERK 1/2, and activated of p38 MAPKs. Arrest in the G0/G1 phase of the cell cycle was also observed afterward chrysin treatment [190, 191]. Nano-encapsulated curcumin-chrysin, decreased expression of MMP-2, MMP-9, and TERT genes and increased expression of TIMP-1 and TIMP-2 genes in mouse B16F10 melanoma tumour model [192].

\section{Uveal melanoma}

Uveal melanoma is the most prevalent intraocular malignancy in adults. Human uveal melanoma cell lines (M17 and SP6.5) were used. Chrysin effect on cell viability and apoptosis, mitochondrial permeability were evaluated by using 3-(4,5-dimethylthiazol-2-yl)-2,5-diphenyltetrazolium bromide and terminal deoxynucleotidyl transferase mediated dUTP nick end-labeling tests and JC-1 fluorescein, respectively. Enzyme-linked immunosorbent assay was used for determine cytosol cytochrome c levels, and the activities of caspase-3, -8 and -9. Pretreatment with chrysin augmented mitochondrial permeability, cytosol cytochrome c levels, and caspases-9 and - 3 activities in M17 and SP6.5 cells. The findings of this study indicated that chrysin induced apoptosis of human uveal melanoma cells through the mitochondrial signaling pathway and recommended that chrysin might be a talented alternative neutraceutical in the management of uveal melanoma. It was found that chrysin caused apoptosis in human uveal melanoma cells through affecting the mitochondrial signaling [193].

\section{Glioma}

Glioma is the most corporate tumor of the CNS in adults $[194,195]$. The effect of chrysin on glioblastoma cell lines and U87 xenografts in nude mice were studied. Cell proliferation was performed by using cell counting Kit- 8 and a plate colony formation assay. Wound-healing test was used for measuring the ability of cell migration. The migration and invasion potential of cells were determined by Transwell migration and Matrigel invasion assay. Western blotting and immunofluorescence staining were used for assessing protein expression. Chrysin deactivated the Nrf2 signaling pathway by declining Nrf2 nuclear translocation and abrogating HO-1 and NQO-1 expression. Also, chrysin downregulated p- ERK1/2, protein expression however did not significantly alter p-P38 and p-JNK expression levels [196, 197]. It was suggested that chrysin induced anticancer activity in glioblastoma cells through the ERK/Nrf2 signaling.

Weng et al. evaluated the effectiveness of pretreatment with chrysin in rat C6 glioma cells by using cell viability, flow cytometric and western blotting analysis. Chrysin attenuated $\mathrm{Rb}$ phosphorylation and caused G1 phase cell cycle arrest. Besides, Chrysin mitigated CDK2 and 4 CDK4 activities and inhibited proteasome activity. Chrysin also induced p38-MAPK activation, resulting in the accumulation of p21 (Waf1/Cip1) protein or arbitrating the inhibition of proteasome activity [198].

\section{Carcinoids}

Carcinoids are neuroendocrine neoplasms characterized by significant rates of morbidity and mortality by the reason of a lack of effective therapeutic agents. Carcinoid cell lines (BON and H727) were utilized. The effect of chrysin on ASCL1 in carcinoid cell was evaluated by using western blotting. propidium iodide and phycoerythrin AnnexinV/7-aminoactinomycin D staining and sorting. Pretreatment with chrysin exposed S/ G2 phase arrest and apoptosis. Interestingly, chrysininduced cleavage of caspase- 3 and PARP and activation of p21Waf1/Cip1. Direct ASCL1 knockdown with an ASCL1-specific, alleviating cyclin B1 and D1 and augmenting expression of p27Kip1 and p21Waf1/Cip1 was 
confirmable involved mechanisms to combat carcinoids. The findings suggested that inhibitory effect of chrysin on ASCL1 was effective for carcinoid management [199].

\section{Leukemia}

Chronic lymphocytic leukemia (CLL) progresses attributable to inequality among apoptosis and proliferation of B lymphocytes. B-CLL cells comprising JVM-13 and MOLT-4 cell lines were investigated. Exposure to chrysin induced activation of Bax and alleviated the expression of Bcl-2 protein, cytochrome c release from mitochondria into the cytosol, and cleaved/activated caspase-3, subsequently leading to the activation of apoptosis of B-CLL cells [200]. Chrysin treatment of CLL B-lymphocytes led to an increase in, ADP/ATP ratio, mitochondrial membrane potential collapse, the formation of ROS, activation of caspase 3, and apoptosis. Chrysin selectively inhibited ATPases and complex II in carcinomatous mitochondria as well [201]. Chrysin increased CD19 (B-cell marker), CD3 (T-cell marker), and Mac-3 (macrophages) cell surface markers and phagocytosis in treated WEHI-3 leukemic mice. Isolated splenocytes from chrysin-administered leukemic mice revealed an intensification of NK cell cytotoxicity [202]. Treatment of T-cell lymphocytes Jurkat cells with chrysin resulted in augmentation of cells proportion in the sub-G0/G1 phase of the cell cycle, which is reflected to be a marker of apoptotic cell death [203]. Lee and coworkers indicated the potent effects of chrysin in MO7e cell proliferation. Chrysin activated ERK5 and accelerated its translocation into the nucleus, and activated CREB and STAT3. Chrysin inhibited cell proliferation via inhibition of the PI3K pathway through SCF/c-Kit signaling and Shc/PDK1/ $\mathrm{PKC} / \mathrm{Akt} / \mathrm{c}-\mathrm{raf}$ signaling cascade [204]. Woo and coworkers utilized U937 cells, chrysin pretreatment activated $\mathrm{Bcl} 2$, and caspase-3 induced and PLC-gammal degradation. The stimulation of apoptotic cell death was also gone along with the down-regulation of X-linked inhibitor of apoptosis (XIAP) and the abrogation of Akt [205]. 8-bromo-7-methoxychrysin in combination with arsenic trioxide induced apoptosis in U937, HL-60, and Jurkat cells. This co-treatment led to cytochrome c release, down-regulation of XIAP and Bcl-XL, and up-regulation of Bax. Moreover due to this co-treatment declined Akt phosphorylation in addition to intracellular GSH content [206].

\section{Osteoblast tumor}

Osteoblasts are necessary for bone homeostasis via deposition of new bone osteoid into resorption pits. Osteoblasts have the main role in cancer cell propagation to bone and metastasis.
It was found that chrysin caused an increase in ROS production in osteoblasts UMR106 tumor cells which might lead to antitumor effects that detected by EPR spectroscopy [207].

\section{Lymphangiogenesis}

Lymphangiogenesis stimulation is the main process for inducing cancer growth and metastasis. Prevention of lymphangiogenesis is the main strategy for cancer therapy [208]. Proliferation assay, cord formation assay, adhesion assay and migration assay were used to determine the efficacy of chrysin in TR-LE cells. Inhibitory effect of chrysin on lymphangiogenesis was responsible for protective effect in TR-LE cells. Chrysin significantly inhibited cord formation, cell adhesion, and migration in rat lymphatic endothelial cells (TR-LE) through inducing VEGF-C mRNA expression and NO production [209].

\section{Angiogenesis}

Unregulated angiogenesis occurs in pathological states including cancer. STAT3 has a main role in the angiogenesis and inflammation processes in tumor metastasis. Chrysin suppressed IL-6-induced angiogenesis in human umbilical vein endothelial cells (HUVECs) and in ovo model of chicken chorioallantoic membrane assay through modulation of the soluble IL-6 receptor /gp130/ JAK1/STAT3/VEGF signaling pathway [210].

Chrysin could inhibit angiogenesis through decrease in the expression of VEGF and IL-6 and also expression of their receptor in HUVECs exposed to lipopolysaccharide (LPS). Indeed, chrysin was able to suppress tumor progression through inhibition inflammatory molecules that involved in angiogenesis [211].

\section{Ehrlich ascites carcinoma}

Ehrlich ascites tumor (EAT) cells were utilized by Orsolić et al. Pretreating with chrysin reduced tumor size and total number of cells in peritoneal cavity of mice affected EAT. Besides, chrysin could increase the marine's survival time and macrophage stimulation [212]. The findings indicated that the anti-tumor effect of chrysin in EAT cells was the results of related to increase in macrophages activity.

Figure 3 indicates the important mechanism underlying the anti-tumor effects of chrysin.

\section{Conclusions and future challenges}

Regarding the broad indications of chrysin in numerous clinical complications, we have defined the current study. Cellular and molecular mechanisms underlying therapeutic applications of chrysin in various cancers have been gathered and discussed. Oxidative stress, 


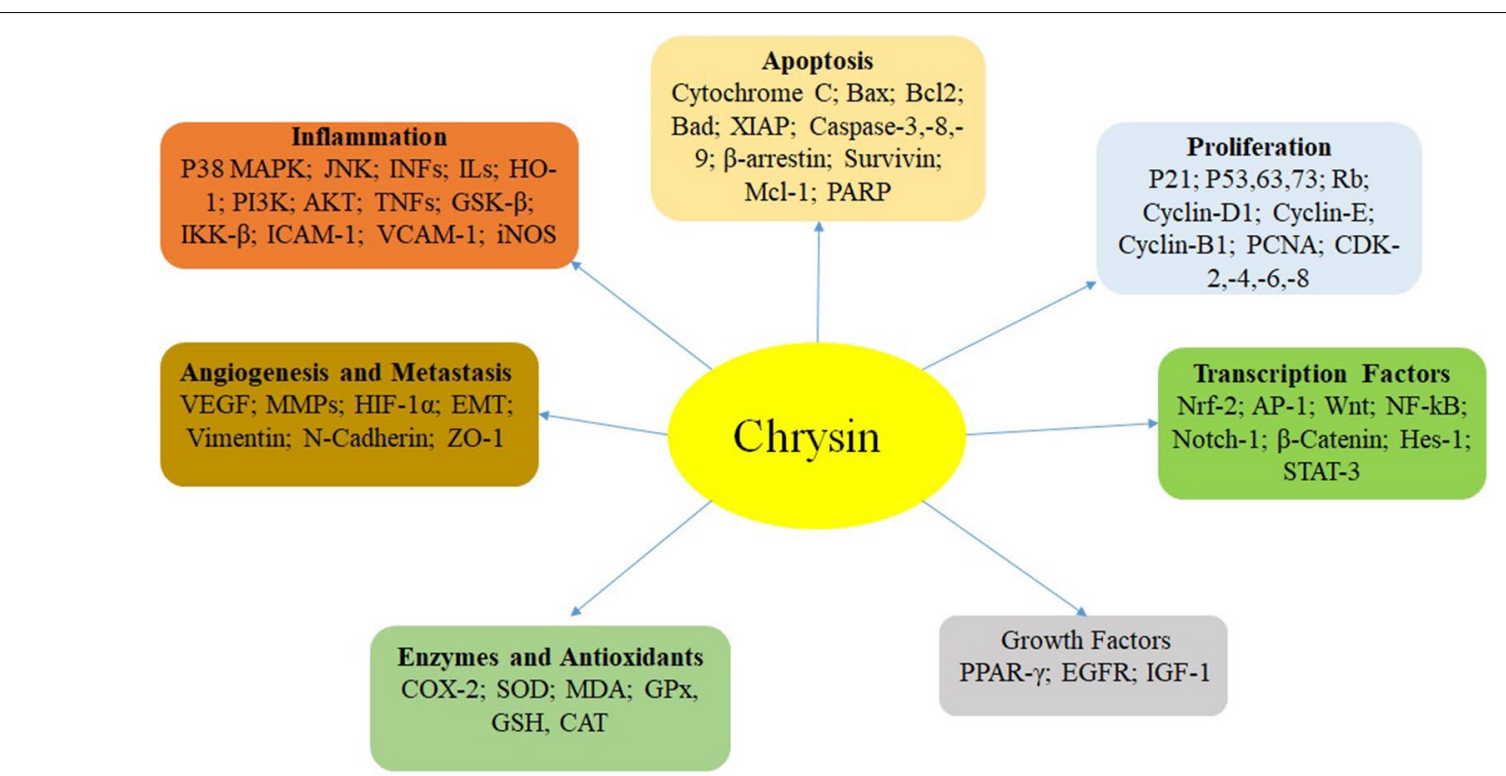

Fig. 3 Important mechanisms involved in the anti-cancer activities of chrysin

inflammatory responses, autophagy, and apoptosis were the most common mechanisms that were affected by chrysin. Chrysin could ameliorate cancers of the breast, gastrointestinal tract, liver and hepatocytes, bladder, male and female reproductive systems, choroid, respiratory tract, thyroid, skin, eye, brain, blood cells, leukemia, osteoblast, and lymph. Likewise, due to the low bioavailability of flavonoids such as chrysin, some modifications comprising a synthesis of analogs, design novel drug delivery systems, and using various carriers would be helpful.

\section{Acknowledgements}

Not-applicable.

\section{Authors' contributions}

MT and SS involved in the conceptualization; validation of resources, and data extraction. MT, MT, TF, DMK, JSG, JB, and SS performed writing the manuscript, MT, TF, SS, and JSG reviewed and edited the manuscript. All of the authors read and approved the final manuscript.

\section{Funding}

This research did not receive funding.

\section{Availability of data and materials}

All data are available in the manuscript.

\section{Declarations}

Ethics approval and consent to participate Not-applicable.

\section{Consent for publication}

Not-applicable.

\section{Competing interests}

There is no competing of interests.

\section{Author details}

${ }^{1}$ Department of Pharmacognosy, School of Pharmacy, Shahid Beheshti University of Medical Sciences, 1991953381 Tehran, Iran. ${ }^{2}$ Department of Chemistry and Biochemistry, University of Texas at Arlington, Arlington, TX 76019, USA. ${ }^{3}$ Food Safety Net Services (FSNS), San Antonio, TX 78216, USA. ${ }^{4}$ Cardiovscular Diseases Research Center, Birjand University of Medical Sciences, Birjand, Iran. ${ }^{5}$ Faculty of Pharmacy, Birjand University of Medical Sciences, Birjand, Iran. ${ }^{6}$ Nutrition and Bromatology Group, Department of Analytical and Food Chemistry, Faculty of Science, University of Vigo, Ourense Campus, 32004 Ourense, Spain. ${ }^{7}$ Institute of Pharmaceutical Technologies, Faculty of Pharmacy, Medical Academy, Lithuanian University of Health Sciences, Sukileliu pr. 13, 50161 Kaunas, Lithuania. ${ }^{8}$ Noncommunicable Diseases Research Center, Neyshabur University of Medical Sciences, Neyshabur, Iran.

Received: 18 October 2020 Accepted: 7 April 2021

Published online: 15 April 2021

\section{References}

1. Siegel RL, Miller KD, Jemal A. Cancer statistics, 2019. CA Cancer J Clin. 2019;69(1):7-34. https://doi.org/10.3322/caac.21551.

2. Ramaswami R, Harding V, Newsom-Davis T. Novel cancer therapies: treatments driven by tumour biology. Postgrad Med J. 2013;89(1057):652. https://doi.org/10.1136/postgradmedj-2012-131533.

3. Nurgali K, Jagoe RT, Abalo R. Editorial: adverse effects of cancer chemotherapy: anything new to improve tolerance and reduce sequelae? Front Pharmacol. 2018:9:245. https://doi.org/10.3389/fphar.2018.00245.

4. Chahar MK, Sharma N, Dobhal MP, Joshi YC. Flavonoids: a versatile source of anticancer drugs. Pharmacogn Rev. 2011;5(9):1-12. https:// doi.org/10.4103/0973-7847.79093.

5. Yadegarynia S, Pham A, Ng A, Nguyen D, Lialiutska T, Bortolazzo A, et al. Profiling flavonoid cytotoxicity in human breast cancer cell lines: determination of structure-function relationships. Nat Prod Commun. 2012:7(10):1295-304. 
6. Talebi M, Ilgün S, Ebrahimi V, Talebi M, Farkhondeh T, Ebrahimi H, et al. Zingiber officinale ameliorates Alzheimer's disease and cognitive impairments: lessons from preclinical studies. Biomed Pharmacother. 2021;133:111088. https://doi.org/10.1016/j.biopha.2020.111088.

7. Siddiqui A, Badruddeen, Akhtar J, Uddin M.S S, Khan MI, Khalid M, et al. A naturally occurring flavone (chrysin): chemistry, occurrence, pharmacokinetic, toxicity, molecular targets and medicinal properties. J Biol Act Prod Nat. 2018;8(4):208-27. https://doi.org/10.1080/22311866.2021. 1887762.

8. Mani R, Natesan V. Chrysin: sources, beneficial pharmacological activities, and molecular mechanism of action. Phytochemistry. 2018;145:187-96. https://doi.org/10.1016/j.phytochem.2017.09.016.

9. Hadjmohammadi MR, Nazari SS. Separation optimization of quercetin, hesperetin and chrysin in honey by micellar liquid chromatography and experimental design. J Sep Sci. 2010;33(20):3144-51. https://doi. org/10.1002/jssc.201000326.

10. Talebi M, Talebi M, Farkhondeh T, Samarghandian S. Molecular mechanism-based therapeutic properties of honey. Biomed Pharmacother 2020;130:110590. https://doi.org/10.1016/j.biopha.2020.110590.

11. Zhao X, Shu G, Chen L, Mi X, Mei Z, Deng X. A flavonoid component from Docynia delavayi (Franch.) Schneid represses transplanted H22 hepatoma growth and exhibits low toxic effect on tumor-bearing mice. Food Chem Toxicol. 2012;50(9):3166-73. https://doi.org/10.1016/j.fct. 2012.05.039.

12. Kamat S, Kumari M, Sajna KV, Jayabaskaran C. Endophytic fungus, Chaetomium globosum, associated with marine green alga, a new source of Chrysin. Sci Rep. 2020;10(1):18726. https://doi.org/10.1038/ s41598-020-72497-3.

13. Boothapandi M, Ravichandran R. Antiproliferative activity of chrysin (5, 7-dihydroxyflavone) from Indigofera tinctoria on human epidermoid carcinoma (A431) cells. Eur J Integr Med. 2018;24:71-8. https://doi.org/ 10.1016/j.eujim.2018.10.015.

14. Chan EWC, Wong SK, Tangah J, Inoue T, Chan HT. A synopsis on flavonoids from the roots of Scutellaria baicalensis with some insights on baicalein and its anti-cancer properties. J Chin Pharm Sci. 2019;28(4):21728. https://doi.org/10.5246/jcps.2019.04.022.

15. da Cunha MG, Franchin M, Galvão L, de Ruiz A, de Carvalho JE, Ikegaki $M$, et al. Antimicrobial and antiproliferative activities of stingless bee Melipona scutellaris geopropolis. BMC Complement Altern Med. 2013;13. https://doi.org/10.1186/1472-6882-13-23.

16. Dinda B, Silsarma I, Dinda M, Rudrapaul P. Oroxylum indicum (L.) Kurz, an important Asian traditional medicine: from traditional uses to scientific data for its commercial exploitation. J Ethnopharmacol. 2015;161:25578. https://doi.org/10.1016/j.jep.2014.12.027.

17. Huang C, Wei YX, Shen MC, Tu YH, Wang CC, Huang HC. Chrysin, abundant in Morinda citrifolia fruit water-EtOAc extracts, combined with apigenin synergistically induced apoptosis and inhibited migration in human breast and liver cancer cells. J Agric Food Chem. 2016;64(21):4235-45. https://doi.org/10.1021/acs.jafc.6b00766.

18. Déciga-Campos M, Mata R, Rivero-Cruz I. Antinociceptive pharmacological profile of Dysphania graveolens in mouse. Biomed Pharmacother. 2017:89:933-8. https://doi.org/10.1016/j.biopha.2017.02.096.

19. Catchpole O, Mitchell K, Bloor S, Davis P, Suddes A. Antiproliferative activity of New Zealand propolis and phenolic compounds vs human colorectal adenocarcinoma cells. Fitoterapia. 2015;106:167-74. https:// doi.org/10.1016/j.fitote.2015.09.004.

20. Harminder, Singh V, Chaudhary AK. A review on the taxonomy, ethnobotany, chemistry and pharmacology of Oroxylum indicum vent. Indian J Pharm Sci. 2011;73(5):483-90. https://doi.org/10.4103/0250-474X. 98981.

21. Zhang Q, Zheng Y, Hu X, Hu X, Lv W, Lv D, et al. Ethnopharmacological uses, phytochemistry, biological activities, and therapeutic applications of Alpinia oxyphylla Miquel: a review. J Ethnopharmacol. 2018;224:14968. https://doi.org/10.1016/j.jep.2018.05.002.

22. Laishram S, Moirangthem DS, Borah JC, Pal BC, Suman P, Gupta SK, et al. Chrysin rich Scutellaria discolor Colebr. induces cervical cancer cell death via the induction of cell cycle arrest and caspase-dependent apoptosis. Life Sci. 2015;143:105-13. https://doi.org/10.1016/j.lfs.2015. 10.035 .

23. Chassagne F, Haddad M, Amiel A, Phakeovilay C, Manithip C, Bourdy $\mathrm{G}$, et al. A metabolomic approach to identify anti-hepatocarcinogenic compounds from plants used traditionally in the treatment of liver diseases. Fitoterapia. 2018;127:226-36. https://doi.org/10.1016/j.fitote. 2018.02.021.

24. Zhang L, Zhang J, Qi B, Jiang G, Liu J, Zhang P, et al. The anti-tumor effect and bioactive phytochemicals of Hedyotis diffusa willd on ovarian cancer cells. J Ethnopharmacol. 2016;192:132-9. https://doi.org/10. 1016/j.jep.2016.07.027.

25. Narayan C, Kumar A. Antineoplastic and immunomodulatory effect of polyphenolic components of Achyranthes aspera (PCA) extract on urethane induced lung cancer in vivo. Mol Biol Rep. 2014;41(1):179-91. https://doi.org/10.1007/s11033-013-2850-6.

26. Chokchaisiri R, Kunkaewom S, Chokchaisiri S, Ganranoo L, Chalermglin R, Suksamrarn A. Potent cytotoxicity against human small cell lung cancer cells of the heptenes from the stem bark of Xylopia pierrei Hance. Med Chem Res. 2017;26(6):1291-6. https://doi.org/10.1007/ s00044-017-1843-8.

27. Wadibhasme PG, Ghaisas MM, Thakurdesai PA. Anti-asthmatic potential of chrysin on ovalbumin-induced bronchoalveolar hyperresponsiveness in rats. Pharm Biol. 2011;49(5):508-15. https://doi.org/10.3109/ 13880209.2010.521754.

28. Li X, Wang JN, Huang JM, Xiong XK, Chen MF, Ong CN, et al. Chrysin promotes tumor necrosis factor (TNF)-related apoptosis-inducing ligand (TRAIL) induced apoptosis in human cancer cell lines. Toxicol In Vitro. 2011;25(3):630-5. https://doi.org/10.1016/j.tiv.2010.12.013.

29. Tsuji PA, Walle T. Benzo[a]pyrene-induced cytochrome P450 $1 \mathrm{~A}$ and DNA binding in cultured trout hepatocytes-inhibition by plant polyphenols. Chem Biol Interact. 2007;169(1):25-31. https://doi.org/10. 1016/j.cbi.2007.05.001.

30. Lirdprapamongkol K, Sakurai H, Abdelhamed S, Yokoyama S, Maruyama T, Athikomkulchai S, et al. A flavonoid chrysin suppresses hypoxic survival and metastatic growth of mouse breast cancer cells. Oncol Rep. 2013;30(5):2357-64. https://doi.org/10.3892/or.2013.2667.

31. Russo P, Del Bufalo A, Cesario A. Flavonoids acting on DNA topoisomerases: recent advances and future perspectives in cancer therapy. Curr Med Chem. 2012;19(31):5287-93. https://doi.org/10.2174/0929867128 03833272.

32. Szkudelski T. The mechanism of alloxan and streptozotocin action in $B$ cells of the rat pancreas. Physiol Res. 2001;50(6):537-46.

33. Bai J, Luo Y, Zhanchun S, Fan W, Wang Z, Luan T, et al. Effects and the mechanisms of chrysin on sepsis-associated acute lung injury of rats Chrysin inhibits acute lung injury. Life Sci J. 2013;10:1052-8.

34. Tian SS, Jiang FS, Zhang K, Zhu XX, Jin B, Lu JJ, et al. Flavonoids from the leaves of Carya cathayensis Sarg. inhibit vascular endothelial growth factor-induced angiogenesis. Fitoterapia. 2014;92:34-40. https://doi. org/10.1016/j.fitote.2013.09.016.

35. Kang MK, Park SH, Choi YJ, Shin D, Kang YH. Chrysin inhibits diabetic renal tubulointerstitial fibrosis through blocking epithelial to mesenchymal transition. J Mol Med. 2015;93(7):759-72. https://doi.org/10. 1007/s00109-015-1301-3.

36. Anandhi R, Thomas PA, Geraldine P. Evaluation of the anti-atherogenic potential of chrysin in Wistar rats. Mol Cell Biochem. 2014;385(1-2):10313. https://doi.org/10.1007/s11010-013-1819-z.

37. Samarghandian S, Azimi-Nezhad M, Samini F, Farkhondeh T. Chrysin treatment improves diabetes and its complications in liver, brain, and pancreas in streptozotocin-induced diabetic rats. Can J Physiol Pharmacol. 2016;94(4):388-93. https://doi.org/10.1139/cjpp-2014-0412.

38. LiY, Li YP, He J, Liu D, Zhang QZ, Li K, et al. The relationship between pharmacological properties and structure-activity of chrysin derivatives. Mini Rev Med Chem. 2019;19(7):555-68. https://doi.org/10.2174/ 1389557518666180424094821.

39. Harris GK, Qian Y, Leonard SS, Sbarra DC, Shi X. Luteolin and chrysin differentially inhibit cyclooxygenase-2 expression and scavenge reactive oxygen species but similarly inhibit prostaglandin-E2 formation in RAW 264.7 cells. J Nutr. 2006;136(6):1517-21. https://doi.org/10.1093/jn/ 136.6.1517.

40. Tsuji PA, Walle T. Cytotoxic effects of the dietary flavones chrysin and apigenin in a normal trout liver cell line. Chem Biol Interact. 2008;171(1):37-44. https://doi.org/10.1016/j.cbi.2007.08.007.

41. Rana AC, Gulliya B. Chemistry and pharmacology of flavonoids-a review. Indian J Pharm Educ Res. 2019;53(1):8-20. https://doi.org/10. 5530/ijper.53.1.3. 
42. Nabavi SF, Braidy N, Habtemariam S, Orhan IE, Daglia M, Manayi A, et al. Neuroprotective effects of chrysin: from chemistry to medicine. Neurochem Int. 2015;90:224-31. https://doi.org/10.1016/j.neuint.2015.09.006.

43. Wang QQ, Cheng N, Yi WB, Peng SM, Zou XQ. Synthesis, nitric oxide release, and a-glucosidase inhibition of nitric oxide donating apigenin and chrysin derivatives. Bioorg Med Chem. 2014;22(5):1515-21. https:// doi.org/10.1016/j.bmc.2014.01.038.

44. Dao TT, Chi YS, Kim J, Kim HP, Kim S, Park H. Synthesis and inhibitory activity against COX-2 catalyzed prostaglandin production of chrysin derivatives. Bioorg Med Chem Lett. 2004;14(5):1165-7. https://doi.org/ 10.1016/j.bmcl.2003.12.087.

45. Zou XQ, Peng SM, Hu CP, Tan LF, Yuan Q, Deng HW, et al. Synthesis, characterization and vasculoprotective effects of nitric oxide-donating derivatives of chrysin. Bioorg Med Chem. 2010;18(9):3020-5. https://doi. org/10.1016/j.bmc.2010.03.056.

46. Peng SM, Zou XQ, Ding HL, Ding YL, Lin YB. Synthesis and promotion angiogenesis effect of chrysin derivatives coupled to NO donors. Bioorg Med Chem Lett. 2009;19(4):1264-6. https://doi.org/10.1016/j.bmcl. 2008.12.116.

47. Park H, Dao TT, Kim HP. Synthesis and inhibition of PGE2 production of 6,8-disubstituted chrysin derivatives. Eur J Med Chem. 2005;40(9):9438. https://doi.org/10.1016/j.ejmech.2005.04.013.

48. Zhu ZY, Wang WX, Wang ZQ, Chen LJ, Zhang JY, Liu XC, et al. Synthesis and antitumor activity evaluation of chrysin derivatives. Eur J Med Chem. 2014;75:297-300. https://doi.org/10.1016/j.ejmech.2013.12.044.

49. Zhang T, Chen X, Qu L, Wu J, Cui R, Zhao Y. Chrysin and its phosphate ester inhibit cell proliferation and induce apoptosis in Hela cells. Bioorg Med Chem. 2004;12(23):6097-105. https://doi.org/10.1016/j.bmc.2004. 09.013.

50. Goto H, Yanagimachi M, Goto S, Takeuchi M, Kato H, Yokosuka T, et al. Methylated chrysin reduced cell proliferation, but antagonized cytotoxicity of other anticancer drugs in acute lymphoblastic leukemia. Anticancer Drugs. 2012;23(4):417-25. https://doi.org/10.1097/CAD. Ob013e32834fb731.

51. Shin JS, Kim KS, Kim MB, Jeong JH, Kim BK. Synthesis and hypoglycemic effect of chrysin derivatives. Bioorg Med Chem Lett. 1999;9(6):869-74. https://doi.org/10.1016/S0960-894X(99)00092-X.

52. Debnath S, Kanakaraju M, Islam M, Yeeravalli R, Sen D, Das A. In silico design, synthesis and activity of potential drug-like chrysin scaffoldderived selective EGFR inhibitors as anticancer agents. Comput Biol Chem. 2019;83. https://doi.org/10.1016/j.compbiolchem.2019.107156.

53. Zhu Y, Yao X, Long J, Li R, Liu Y, Yang Z, et al. Fluorine-containing chrysin derivatives: synthesis and biological activity. Nat Prod Commun. 2019;14(9). https://doi.org/10.1177/1934578X19878921.

54. Mistry BM, Patel RV, Keum YS, Kim DH. Chrysin-benzothiazole conjugates as antioxidant and anticancer agents. Bioorg Med Chem Lett. 2015;25(23):5561-5. https://doi.org/10.1016/j.bmcl.2015.10.052.

55. Walle T, Otake Y, Brubaker JA, Walle UK, Halushka PV. Disposition and metabolism of the flavonoid chrysin in normal volunteers. Br J Clin Pharmacol. 2001;51(2):143-6. https://doi.org/10.1111/j.1365-2125.2001. 01317.x.

56. Galijatovic A, Otake Y, Walle UK, Walle T. Extensive metabolism of the flavonoid chrysin by human Caco-2 and Hep G2 cells. Xenobiotica. 1999;29(12):1241-56. https://doi.org/10.1080/004982599237912.

57. Ge S, Gao S, Yin T, Hu M. Determination of pharmacokinetics of chrysin and its conjugates in wild-type FVB and Bcrp1 knockout mice using a validated LC-MS/MS method. J Agric Food Chem. 2015;63(11):2902-10. https://doi.org/10.1021/jf5056979.

58. Kao YC, Zhou C, Sherman M, Laughton CA, Chen S. Molecular basis of the inhibition of human aromatase (estrogen synthetase) by flavone and isoflavone phytoestrogens: a site-directed mutagenesis study. Environ Health Perspect. 1998;106(2):85-92. https://doi.org/10.1289/ ehp.9810685.

59. Anari E, Akbarzadeh A, Zarghami N. Chrysin-loaded PLGA-PEG nanoparticles designed for enhanced effect on the breast cancer cell line. Artif Cells Nanomed Biotechnol. 2016;44(6):1410-6. https://doi.org/10.3109/ 21691401.2015.1029633.

60. Liang Y, Deng X, Zhang L, Peng X, Gao W, Cao J, et al. Terminal modification of polymeric micelles with $\pi$-conjugated moieties for efficient anticancer drug delivery. Biomaterials. 2015;71:1-10. https://doi.org/10. 1016/j.biomaterials.2015.08.032.
61. Davatgaran-Taghipour Y, Masoomzadeh S, Farzaei MH, Bahramsoltani R, Karimi-Soureh Z, Rahimi R, et al. Polyphenol nanoformulations for cancer therapy: experimental evidence and clinical perspective. Int J Nanomed. 2017;12:2689-702. https://doi.org/10.2147/IJN.S131973.

62. Deldar Y, Pilehvar-Soltanahmadi Y, Dadashpour M, Montazer Saheb S, Rahmati-Yamchi M, Zarghami N. An in vitro examination of the antioxidant, cytoprotective and anti-inflammatory properties of chrysinloaded nanofibrous mats for potential wound healing applications. Artif Cells Nanomed Biotechnol. 2018;46(4):706-16. https://doi.org/10. 1080/21691401.2017.1337022.

63. Lee JA, Jung BG, Kim TH, Kim YM, Park MH, Hyun PM, et al. Poly D, L-lactide-co-glycolide (PLGA) nanoparticle-encapsulated honeybee (Apis melifera) venom promotes clearance of Salmonella enterica serovar Typhimurium infection in experimentally challenged pigs through the up-regulation of T helper type 1 specific immune responses. Vet Immunol Immunopathol. 2014;161(3-4):193-204. https://doi.org/10.1016/j. vetimm.2014.08.010.

64. Arafa MG, Ghalwash D, El-Kersh DM, Elmazar MM. Propolis-based niosomes as oromuco-adhesive films: a randomized clinical trial of a therapeutic drug delivery platform for the treatment of oral recurrent aphthous ulcers. Sci Rep. 2018;8(1):18056. https://doi.org/10.1038/ s41598-018-37157-7.

65. Mohammadinejad S, Akbarzadeh A, Rahmati M, Hatam S, Kachalaki S, Sanaat Z, et al. Preparation and evaluation of chrysin encapsulated in PLGA- PEG nanoparticles in the T47-D breast cancer cell line. Asian Pac J Cancer Prev. 2015;16:3753-8. https://doi.org/10.7314/apjcp.2015.16.9. 3753.

66. Bagheri R, Sanaat Z, Zarghami N. Synergistic effect of free and nanoencapsulated chrysin-curcumin on inhibition of hTERT gene expression in SW480 colorectal cancer cell line. Drug Res. 2018;68(6):335-43. https://doi.org/10.1055/s-0043-121338.

67. Zheng H, Li S, Pu Y, Lai Y, He B, Gu Z. Nanoparticles generated by PEGChrysin conjugates for efficient anticancer drug delivery. Eur J Pharm Biopharm. 2014;87(3):454-60. https://doi.org/10.1016/j.ejpb.2014.03. 011.

68. Sabzichi M, Mohammadian J, Bazzaz R, Pirouzpanah MB, Shaaker M, Hamishehkar $\mathrm{H}$, et al. Chrysin loaded nanostructured lipid carriers (NLCs) triggers apoptosis in MCF-7 cancer cells by inhibiting the Nrf2 pathway. Process Biochem. 2017;60:84-91. https://doi.org/10.1016/j. procbio.2017.05.024.

69. Liang Y, Peng X, Chen Y, Deng X, Gao W, Cao J, et al. Chain length effect on drug delivery of chrysin modified mPEG-PCL micelles. RSC Adv. 2015;5(73):59014-21. https://doi.org/10.1039/C5RA09650B.

70. Davaran S, Fazeli H, Ghamkhari A, Rahimi F, Molavi O, Anzabi M, et al. Synthesis and characterization of novel P(HEMA-LA-MADQUAT) micelles for co-delivery of methotrexate and chrysin in combination cancer chemotherapy. J Biomater Sci Polym Ed. 2018;29(11):1265-86. https://doi.org/10.1080/09205063.2018.1456026.

71. Dhawan K, Kumar S, Sharma A. Beneficial effects of chrysin and benzoflavone on virility in 2-year-old male rats. J Med Food. 2002;5(1):43-8. https://doi.org/10.1089/109662002753723214.

72. Tobin PJ, Beale P, Noney L, Liddell S, Rivory LP, Clarke S. A pilot study on the safety of combining chrysin, a non-absorbable inducer of UGT1A1, and irinotecan (CPT-11) to treat metastatic colorectal cancer. Cancer Chemother Pharmacol. 2006;57(3):309-16. https://doi.org/10.1007/ s00280-005-0053-0.

73. Naz S, Imran M, Rauf A, Orhan IE, Shariati MA, lahtisham UI H, et al. Chrysin: pharmacological and therapeutic properties. Life Sci. 2019;235:116797. https://doi.org/10.1016/j.lfs.2019.116797.

74. Gardner I, Popović M, Zahid N, Uetrecht JP. A comparison of the covalent binding of clozapine, procainamide, and vesnarinone to human neutrophils in vitro and rat tissues in vitro and in vivo. Chem Res Toxicol. 2005;18(9):1384-94. https://doi.org/10.1021/tx050095o.

75. Kim KM, Jung J. Upregulation of G protein-coupled estrogen receptor by chrysin-nanoparticles inhibits tumor proliferation and metastasis in triple negative breast cancer xenograft model. Front Endocrinol. 2020;11. https://doi.org/10.3389/fendo.2020.560605.

76. Nagasaka M, Hashimoto $R$, Inoue $Y$, Ishiuchi $K$, Matsuno $M$, Itoh $Y$, et al. Anti-tumorigenic activity of chrysin from oroxylum indicum via nongenotoxic p53 activation through the ATM-Chk2 pathway. Molecules. 2018;23(6):1394. https://doi.org/10.3390/molecules23061394. 
77. Rasouli S, Zarghami N. Synergistic growth inhibitory effects of chrysin and metformin combination on breast cancer cells through hTERT and cyclin D1 suppression. Asian Pac J Cancer Prev. 2018;19(4):977-82. https://doi.org/10.22034/APJCP.2018.19.4.977.

78. Javan Maasomi Z, Pilehvar Soltanahmadi Y, Dadashpour M, Alipour S, Abolhasani S, Zarghami N. Synergistic anticancer effects of silibinin and chrysin in T47D breast cancer cells. Asian Pac J Cancer Prev. 2017;18(5):1283-7. https://doi.org/10.22034/APJCP.2017.18.5.1283.

79. Samarghandian S, Azimi-Nezhad M, Borji A, Hasanzadeh M, Jabbari F, Farkhondeh T, et al. Inhibitory and cytotoxic activities of chrysin on human breast adenocarcinoma cells by induction of apoptosis. Pharmacogn Mag. 2016;12(Suppl 4):S436-40. https://doi.org/10.4103/ 0973-1296.191453.

80. Yang B, Huang J, Xiang T, Yin X, Luo X, Huang J, et al. Chrysin inhibits metastatic potential of human triple-negative breast cancer cells by modulating matrix metalloproteinase-10, epithelial to mesenchymal transition, and PI3K/Akt signaling pathway. J Appl Toxicol. 2014;34(1):105-12. https://doi.org/10.1002/jat.2941.

81. Ding J, Polier G, Kö̈ler R, Giaisi M, Krammer PH, Li-Weber M. Wogonin and related natural flavones overcome tumor necrosis factor-related apoptosis-inducing ligand (TRAIL) protein resistance of tumors by down-regulation of c-FLIP protein and up-regulation of TRAIL receptor 2 expression. J Biol Chem. 2012;287(1):641-9. https://doi.org/10.1074/ jbc.M111.286526.

82. Sassa-Deepaeng T, Chaisri W, Pikulkaew S, Okonogi S. Investigation of antiaromatase activity using hepatic microsomes of Nile tilapia (Oreochromis niloticus). Drug Discov Ther. 2017;11(2):84-90. https://doi.org/ 10.5582/ddt.2017.01006.

83. Hong TB, Rahumatullah A, Yogarajah T, Ahmad M, Yin KB. Potential effects of chrysin on MDA-MB-231 cells. Int J Mol Sci. 2010;11(3):105769. https://doi.org/10.3390/ijms11031057.

84. Manupati K, Dhoke NR, Debnath T, Yeeravalli R, Guguloth K, Saeidpour $\mathrm{S}$, et al. Inhibiting epidermal growth factor receptor signalling potentiates mesenchymal-epithelial transition of breast cancer stem cells and their responsiveness to anticancer drugs. FEBS J. 2017;284(12):1830-54. https://doi.org/10.1111/febs.14084.

85. Xuan $\mathrm{HZ}$, Zhang $\mathrm{JH}$, Wang $\mathrm{YH}, \mathrm{Fu} \mathrm{CL}$, Zhang W. Anti-tumor activity evaluation of novel chrysin-organotin compound in MCF-7 cells. Bioorg Med Chem Lett. 2016;26(2):570-4. https://doi.org/10.1016/j.bmcl.2015. 11.072.

86. Roy S, Sil A, Chakraborty T. Potentiating apoptosis and modulation of p53, Bcl2, and Bax by a novel chrysin ruthenium complex for effective chemotherapeutic efficacy against breast cancer. J Cell Physiol. 2019;234(4):4888-909. https://doi.org/10.1002/jcp.27287.

87. Zhang $S$, Yang $X$, Morris ME. Flavonoids are inhibitors of breast cancer resistance protein (ABCG2)-mediated transport. Mol Pharmacol. 2004;65(5):1208-16. https://doi.org/10.1124/mol.65.5.1208.

88. Cao XZ, Xiang HL, Quan MF, He LH. Inhibition of cell growth by BrMC through inactivation of Akt in HER-2/neu-overexpressing breast cancer cells. Oncol Lett. 2014;7(5):1632-8. https://doi.org/10.3892/ol.2014. 1889 .

89. Zhao XC, Cao XC, Liu F, Quan MF, Ren KQ, Cao JG. Regulation of the FOXO3a/bim signaling pathway by 5,7-dihydroxy-8-nitrochrysin in MDA-MB-453 breast cancer cells. Oncol Lett. 2013;5(3):929-34. https:// doi.org/10.3892/ol.2012.1077.

90. Al-Oudat BA, Alqudah MA, Audat SA, Al-Balas QA, El-Elimat T, Hassan $M A$, et al. Design, synthesis, and biologic evaluation of novel chrysin derivatives as cytotoxic agents and caspase-3/7 activators. Drug Des Devel Ther. 2019;13:423-33. https://doi.org/10.2147/DDDT.S189476.

91. Gnanasekar S, Balakrishnan D, Seetharaman P, Arivalagan P, Chandrasekaran R, Sivaperumal S. Chrysin-anchored silver and gold nanoparticle-reduced graphene oxide composites for breast cancer therapy. ACS Appl Nano Mater. 2020;3(5):4574-85. https://doi.org/10. 1021/acsanm.0c00630.

92. Eatemadi A, Daraee H, Aiyelabegan HT, Negahdari B, Rajeian B, Zarghami N. Synthesis and characterization of chrysin-loaded PCL-PEG-PCL nanoparticle and its effect on breast cancer cell line. Biomed Pharmacother. 2016;84:1915-22. https://doi.org/10.1016/j.biopha.2016.10.095.

93. Zhong X, Liu D, Jiang Z, Li C, Chen L, Xia Y, et al. Chrysin induced cell apoptosis and inhibited invasion through regulation of TET1 expression in gastric cancer cells. Onco Targets Ther. 2020;13:3277-87. https://doi. org/10.2147/OTT.S302177.

94. Mohammadian F, Pilehvar-Soltanahmadi Y, Alipour S, Dadashpour M, Zarghami N. Chrysin alters microRNAs expression levels in gastric cancer cells: possible molecular mechanism. Drug Res. 2017;67(9):509-14. https://doi.org/10.1055/s-0042-119647.

95. Mohammadian F, Abhari A, Dariushnejad H, Nikanfar A, Pilehvar-Soltanahmadi Y, Zarghami N. Effects of chrysin-PLGA-PEG nanoparticles on proliferation and gene expression of mirnas in gastric cancer cell line. Int J Cancer Manag. 2016;9(4). https://doi.org/10.17795/ijcp-4190.

96. Mohammadian F, Pilehvar-Soltanahmadi Y, Zarghami F, Akbarzadeh A, Zarghami N. Upregulation of miR-9 and Let-7a by nanoencapsulated chrysin in gastric cancer cells. Artif Cells Nanomed Biotechnol. 2017;45(6):1201-6. https://doi.org/10.1080/21691401.2016.1216854.

97. Mohammadian F, Pilehvar-Soltanahmadi Y, Mofarrah M, DastaniHabashi M, Zarghami N. Down regulation of miR-18a, miR-21 and miR-221 genes in gastric cancer cell line by chrysin-loaded PLGA-PEG nanoparticles. Artif Cells Nanomed Biotechnol. 2016;44(8):1972-8. https://doi.org/10.3109/21691401.2015.1129615.

98. Xia Y, Lian S, Khoi PN, Yoon HJ, Joo YE, Chay KO, et al. Chrysin inhibits tumor promoter-induced MMP-9 expression by blocking AP-1 via suppression of ERK and JNK pathways in gastric cancer cells. PLOS ONE. 2015;10(4). https://doi.org/10.1371/journal.pone.0124007.

99. Xia Y, Lian S, Khoi PN, Yoon HJ, Han JY, Chay KO, et al. Chrysin inhibits cell invasion by inhibition of Recepteur d'origine Nantais via suppressing early growth response-1 and NF-kB transcription factor activities in gastric cancer cells. Int J Oncol. 2015;46(4):1835-43. https://doi.org/10. 3892/ijo.2015.2847.

100. Bakhsheshian J, Hall MD, Robey RW, Herrmann MA, Chen JQ, Bates SE, et al. Overlapping substrate and inhibitor specificity of human and murine ABCG2. Drug Metab Dispos. 2013;41(10):1805-12. https://doi. org/10.1124/dmd.113.053140.

101. Wang Z, Deng X, Xiong S, Xiong R, Liu J, Zou L, et al. Design, synthesis and biological evaluation of chrysin benzimidazole derivatives as potential anticancer agents. Nat Prod Res. 2018;32(24):2900-9. https:// doi.org/10.1080/14786419.2017.1389940.

102. Ai XH, Zheng $X$, Tang $X Q$, Sun $L$, Zhang $Y Q$, Qin $Y$, et al. Induction of apoptosis of human gastric carcinoma SGC-7901 cell line by 5, 7-dihydroxy-8-nitrochrysin in vitro. World J Gastroenterol. 2007;13(28):3824-8. https://doi.org/10.3748/wjg.v13.i28.3824.

103. Lee S, Lee SK, Jung J. Potentiating activities of chrysin in the therapeutic efficacy of 5-fluorouracil in gastric cancer cells. Oncol Lett. 2021;21(1):17. https://doi.org/10.3892/ol.2020.12285.

104. Xiang HL, Zheng X, Cao JG. Induction of apoptosis of human gastric carcinoma SGC-7901 cell line by 8-bromo-7-methoxychrysin. Chin Pharmacol Bull. 2008;24(10):1370-2.

105. Liu Y, Song X, Ma J, He J, Zheng X, Lei $X$, et al. Synthesis of new 7-O-modified chrysin derivatives and their anti-proliferative and apoptotic effects on human gastric carcinoma MGC-803 cells. Chem Res Chin Univ. 2014;30(6):925-30. https://doi.org/10.1007/ s40242-014-4269-6.

106. Araújo JR, Gonçalves $P$, Martel F. Chemopreventive effect of dietary polyphenols in colorectal cancer cell lines. Nutr Res. 2011;31(2):77-87. https://doi.org/10.1016/j.nutres.2011.01.006.

107. Lin YM, Chen Cl, Hsiang YP, Hsu YC, Cheng KC, Chien PH, et al. Chrysin attenuates cell viability of human colorectal cancer cells through autophagy induction unlike 5-fluorouracil/oxaliplatin. Int J Mol Sci. 2018;19(6). https://doi.org/10.3390/ijms19061763.

108. Ronnekleiv-Kelly SM, Nukaya M, Díaz-Díaz CJ, Megna BW, Carney PR, Geiger PG, et al. Aryl hydrocarbon receptor-dependent apoptotic cell death induced by the flavonoid chrysin in human colorectal cancer cells. Cancer Lett. 2016;370(1):91-9. https://doi.org/10.1016/j.canlet. 2015.10.014.

109. Bahadori M, Baharara J, Amini E. Anticancer properties of chrysin on colon cancer cells, in vitro and in vivo with modulation of caspase-3, -9, Bax and sall4. Iran J Biotechnol. 2016;14(3):177-84. https://doi.org/10. 15171/JJB.1374.

110. Schumacher M, Hautzinger A, Rossmann A, Holzhauser S, Popovic D, Hertrampf A, et al. Chrysin blocks topotecan-induced apoptosis in Caco-2 cells in spite of inhibition of ABC-transporters. Biochem Pharmacol. 2010;80(4):471-9. https://doi.org/10.1016/j.bcp.2010.04.038. 
111. Romier B, Van De Walle J, During A, Larondelle Y, Schneider YJ. Modulation of signalling nuclear factor-kappaB activation pathway by polyphenols in human intestinal Caco-2 cells. Br J Nutr. 2008;100(3):542-51. https://doi.org/10.1017/S0007114508966666.

112. León IE, Cadavid-Vargas JF, Tiscornia I, Porro V, Castelli S, Katkar P, et al. Oxidovanadium(IV) complexes with chrysin and silibinin: anticancer activity and mechanisms of action in a human colon adenocarcinoma model. J Biol Inorg Chem. 2015;20(7):1175-91. https://doi.org/10.1007/ s00775-015-1298-7.

113. Choi JK, Jang YH, Lee S, Lee SR, Choi YA, Jin M, et al. Chrysin attenuates atopic dermatitis by suppressing inflammation of keratinocytes. Food Chem Toxicol. 2017;1 10:142-50. https://doi.org/10.1016/j.fct.2017.10. 025.

114. Galijatovic A, Otake Y, Walle UK, Walle T. Induction of UDP-glucuronosyltransferase UGT1A1 by the flavonoid chrysin in Caco-2 cells-potential role in carcinogen bioinactivation. Pharm Res. 2001;18(3):374-9. https:// doi.org/10.1023/a:1011019417236.

115. Bhardwaj M, Kim NH, Paul S, Jakhar R, Han J, Kang SC. 5-Hydroxy7-methoxyflavone triggers mitochondrial-associated cell death via reactive oxygen species signaling in human colon carcinoma cells. PLoS ONE. 2016;11(4). https://doi.org/10.1371/journal.pone.0154525.

116. Salama AAA, Allam RM. Promising targets of chrysin and daidzein in colorectal cancer: amphiregulin, CXCL1, and MMP-9. Eur J Pharmacol. 2021;892. https://doi.org/10.1016/j.ejphar.2020.173763.

117. Ren J, Cheng H, Xin WQ, Chen X, Hu K. Induction of apoptosis by 7-piperazinethylchrysin in HCT-116 human colon cancer cells. Oncol Rep. 2012;28(5):1719-26. https://doi.org/10.3892/or.2012.2016.

118. Khoo BY, Chua SL, Balaram P. Apoptotic effects of chrysin in human cancer cell lines. Int J Mol Sci. 2010;11(5). https://doi.org/10.3390/ijms1 1052188.

119. Zhang Q, Zhao XH, Wang ZJ. Cytotoxicity of flavones and flavonols to a human esophageal squamous cell carcinoma cell line (KYSE-510) by induction of G2/M arrest and apoptosis. Toxicol In Vitro. 2009;23(5):797807. https://doi.org/10.1016/j.tiv.2009.04.007.

120. Zhang Q, Zhao XH, Wang ZJ. Flavones and flavonols exert cytotoxic effects on a human oesophageal adenocarcinoma cell line (OE33) by causing G2/M arrest and inducing apoptosis. Food Chem Toxicol. 2008:46(6):2042-53. https://doi.org/10.1016/j.fct.2008.01.049.

121. Wang ZJ, Zhang Q, Li TJ, Zhao XH. A possible molecular mechanism of two flavones and two flavonols on the induction of differentiation in a human oesophageal adenocarcinoma cell line (OE33). J Med Plant Res. 2011;5(13):2652-64

122. Zhang Q, Zhao XH. Molecular mechanism of flavones and flavonols on the induction of cell cycle arrest in human esophageal carcinoma cells. Prog Biochem Biophys. 2008;35(9):1031-8.

123. Celińska-Janowicz K, Zaręba I, Lazarek U, Teul J, Tomczyk M, Pałka J, et al. Constituents of propolis: chrysin, caffeic acid, $p$-coumaric acid, and ferulic acid Induce PRODH/POX-dependent apoptosis in human tongue squamous cell carcinoma cell (CAL-27). Front Pharmacol. 2018;9:336. https://doi.org/10.3389/fphar.2018.00336.

124. Xie Y, Peng X (2019). Effects of chrysin on the apoptosis in oral squamous carcinoma kb cell line and the underlying mechanisms. J Cent South Univ Med Sci. 2019;44(5):522-7. Doi: https://doi.org/10.11817/j. issn.1672-7347.2019.05.008.

125. Bishayee A, Thoppil RJ, Waghray A, Kruse JA, Novotny NA, Darvesh AS. Dietary phytochemicals in the chemoprevention and treatment of hepatocellular carcinoma: in vivo evidence, molecular targets, and clinical relevance. Curr Cancer Drug Targets. 2012;12(9):1191-232. https:// doi.org/10.2174/15680096112091191.

126. Zhang Y, Chen F, Xiao X, Pan W, Yuan Q, Cao J. Chrysin inhibits sphere formation in SMMC-7721 cells via modulation of SHP-1/STAT3 signaling pathway. Cancer Manag Res. 2019;11:2977-85. https://doi.org/10.2147/ CMAR.S193647.

127. Wei $C T$, Chen LC, Hsiang YP, Hung YJ, Chien PH, Pan HL, et al. Chrysin-induced ERK1/2 phosphorylation enhances the sensitivity of human hepatocellular carcinoma cells to sorafenib. Anticancer Res. 2019;39(2):695-701. https://doi.org/10.21873/anticanres.13165.

128. Seydi E, Rahimpour Z, Salimi A, Pourahmad J. Selective toxicity of chrysin on mitochondria isolated from liver of a HCC rat model. Bioorg Med Chem. 2019;27(24):115163. https://doi.org/10.1016/j.bmc.2019.115163.
129. Xu D, Jin J, Yu H, Zhao Z, Ma D, Zhang C, et al. Chrysin inhibited tumor glycolysis and induced apoptosis in hepatocellular carcinoma by targeting hexokinase-2. J Exp Clin Cancer Res. 2017;36(1):44. https://doi. org/10.1186/s13046-017-0514-4.

130. Zhang Q, Ma S, Liu B, Liu J, Zhu R, Li M. Chrysin induces cell apoptosis via activation of the $\mathrm{p} 53 / \mathrm{BCl}-2 /$ caspase-9 pathway in hepatocellular carcinoma cells. Exp Ther Med. 2016;12(1):469-74. https://doi.org/10. 3892/etm.2016.3282.

131. Li X, Huang JM, Wang JN, Xiong XK, Yang XF, Zou F. Combination of chrysin and cisplatin promotes the apoptosis of Hep G2 cells by upregulating p53. Chem Biol Interact. 2015;232:12-20. https://doi.org/10. 1016/j.cbi.2015.03.003.

132. Oliveira GA, Ferraz ER, Souza AO, Lourenço RA, Oliveira DP, Dorta DJ. Evaluation of the mutagenic activity of chrysin, a flavonoid inhibitor of the aromatization process. J Toxicol Environ Health Part A. 2012;75(1617):1000-11. https://doi.org/10.1080/15287394.2012.696517.

133. Gao AM, Ke ZP, Shi F, Sun GC, Chen H. Chrysin enhances sensitivity of BEL-7402/ADM cells to doxorubicin by suppressing PI3K/Akt/Nrf2 and ERK/Nrf2 pathway. Chem Biol Interact. 2013;206(1):100-8. https://doi. org/10.1016/j.cbi.2013.08.008.

134. Talebi M, Talebi M, Farkhondeh T, Mishra G, Ilgün S, Samarghandian S. New insights into the role of the Nrf2 signaling pathway in green tea catechin applications. Phytother Res. 2021. https://doi.org/10.1002/ptr. 7033.

135. Sun X, Huo X, Luo T, Li M, Yin Y, Jiang Y. The anticancer flavonoid chrysin induces the unfolded protein response in hepatoma cells. J Cell Mol Med. 2011;15(11):2389-98. https://doi.org/10.1111/j.1582-4934.2010. 01244.x.

136. Khan MS, Devaraj H, Devaraj N. Chrysin abrogates early hepatocarcinogenesis and induces apoptosis in N-nitrosodiethylamine-induced preneoplastic nodules in rats. Toxicol Appl Pharmacol. 2011;251(1):85-94. https://doi.org/10.1016/j.taap.2010.12.004.

137. Walle T, Otake Y, Galijatovic A, Ritter JK, Walle UK. Induction of UDPglucuronosyltransferase UGT1A1 by the flavonoid chrysin in the human hepatoma cell line hep G2. Drug Metab Dispos. 2000;28(9):1077-82.

138. Sherif IO, Al-Mutabagani LA, Sabry D, Elsherbiny NM. Antineoplastic activity of chrysin against human hepatocellular carcinoma: new insight on gpc3/sulf2 axis and Incrna-af085935 expression. Int J Mol Sci. 2020;21(20):1-14. https://doi.org/10.3390/ijms21207642.

139. Wang ZP, Zhou Q, Shi HZ, Xiong S, Wang YF. Anti-hepatocarcinoma effects of a food additive chrysin nanosuspension against human HepG2 cells. Adv J Food Sci Technol. 2015;7(8):627-30.

140. Khan MS, Halagowder D, Devaraj SN. Methylated chrysin induces co-ordinated attenuation of the canonical Wnt and NF-kB signaling pathway and upregulates apoptotic gene expression in the early hepatocarcinogenesis rat model. Chem Biol Interact. 2011;193(1):12-21. https://doi.org/10.1016/j.cbi.2011.04.007.

141. Yang XH, Zheng X, Cao JG, Xiang HL, Liu F, Lv Y. 8-bromo-7-methoxychrysin-induced apoptosis of hepatocellular carcinoma cells involves ROS and JNK. World J Gastroenterol. 2010;16(27):3385-93. https://doi. org/10.3748/wjg.v16.i27.3385.

142. Rashid S, Nafees S, Vafa A, Afzal SM, Ali N, Rehman MU, et al. Inhibition of precancerous lesions development in kidneys by chrysin via regulating hyperproliferation, inflammation and apoptosis at pre clinical stage. Arch Biochem Biophys. 2016;606:1-9. https://doi.org/10.1016/j.abb. 2016.07.004.

143. Rehman MU, Tahir M, Khan AQ, Khan R, Lateef A, Oday OH, et al. Chrysin suppresses renal carcinogenesis via amelioration of hyperproliferation, oxidative stress and inflammation: plausible role of NF-KB. Toxicol Lett. 2013;216(2-3):146-58. https://doi.org/10.1016/j.toxlet.2012.11.013.

144. Xu Y, Tong Y, Ying J, Lei Z, Wan L, Zhu X, et al. Chrysin induces cell growth arrest, apoptosis, and ER stress and inhibits the activation of STAT3 through the generation of ROS in bladder cancer cells. Oncol Lett. 2018;15(6):9117-25. https://doi.org/10.3892/ol.2018.8522.

145. Lima APB, Almeida TC, Barros TMB, Rocha LCM, Garcia CCM, da Silva GN. Toxicogenetic and antiproliferative effects of chrysin in urinary bladder cancer cells. Mutagenesis. 2020. https://doi.org/10.1093/mutage/geaa0 21.

146. Talebi M, Talebi M, Kakouri E, Farkhondeh T, Pourbagher-Shahri AM, Tarantilis PA, et al. Tantalizing role of p53 molecular pathways and its coherent medications in neurodegenerative diseases. Int J Biol 
Macromol. 2021;172:93-103. https://doi.org/10.1016/j.ijbiomac.2021.01. 042.

147. Szliszka E, Gebka J, Bronikowska J, Krol W. Dietary flavones enhance the effect of tumor necrosis factor-related apoptosis-inducing ligand (TRAIL) on bladder cancer cells. Cent European J Urol. 2010;63(3):138-43.

148. Oršolić N, Štajcar D, Bašić I. Propolis and its flavonoid compounds cause cytotoxicity on human urinary bladder transitional cell carcinoma in primary culture. Period Biol. 2009;111(1):113-21.

149. Sak K, Lust H, Kase M, Saar M, Jaal J. Suppression of taxanes cytotoxicity by citrus flavonoid hesperetin in PPC-1 human prostate cancer cells, Anticancer Res. 2018;38(11):6209-15. https://doi.org/10.21873/antic anres. 12975.

150. Ryu S, Lim W, Bazer FW, Song G. Chrysin induces death of prostate cancer cells by inducing ROS and ER stress. J Cell Physiol. 2017;232(12):3786-97. https://doi.org/10.1002/jcp.25861.

151. Samarghandian S, Afshari JT, Davoodi S. Chrysin reduces proliferation and induces apoptosis in the human prostate cancer cell line pc-3. Clinics (Sao Paulo). 2011;66(6):1073-9. https://doi.org/10.1590/S1807-59322 011000600026.

152. Abel SDA, Dadhwal S, Gamble AB, Baird SK. Honey reduces the metastatic characteristics of prostate cancer cell lines by promoting a loss of adhesion. PeerJ. 2018;2018(7). https://doi.org/10.7717/peerj.5115.

153. Fu B, Xue J, Li Z, Shi X, Jiang BH, Fang J. Chrysin inhibits expression of hypoxia-inducible factor 1 -a through reducing hypoxia-inducible factor-1a stability and inhibiting its protein synthesis. Mol Cancer Ther. 2007:6(1):220-6. https://doi.org/10.1158/1535-7163.MCT-06-0526.

154. Szliszka E, Sokół-Łętowska A, Kucharska AZ, Jaworska D, Czuba ZP, Król W. Ethanolic extract of polish propolis: chemical composition and TRAIL-R2 death receptor targeting apoptotic activity against prostate cancer cells. Evid Based Complement Alternat Med. 2013;2013:757628. https://doi.org/10.1155/2013/757628.

155. Li $\mathrm{H}$, Chen $\mathrm{A}$, Yuan $\mathrm{Q}$, Chen $\mathrm{W}$, Zhong $\mathrm{H}$, Teng $\mathrm{M}$, et al. NF-KB/Twist axis is involved in chysin inhibition of ovarian cancer stem cell features induced by co-treatment of TNF- $\alpha$ and TGF- $\beta$. Int J Clin Exp Pathol. 2019;12(1):101-12.

156. Lim W, Ryu S, Bazer FW, Kim SM, Song G. Chrysin attenuates progression of ovarian cancer cells by regulating signaling cascades and mitochondrial dysfunction. J Cell Physiol. 2018;233(4):3129-40. https://doi.org/10. 1002/jcp.26150

157. Pourbagher-Shahri AM, Farkhondeh T, Ashrafizadeh M, Talebi M, Samargahndian S. Curcumin and cardiovascular diseases: focus on cellular targets and cascades. Biomed Pharmacother. 2021;136:111214. https:// doi.org/10.1016/j.biopha.2020.111214.

158. Li H, Chen Y, Fang Y, Zhong L, Yuan Q, Xu X, et al. Effects of chrysin on sphere formation and CK2a expression of ovarian cancer stem-like cells derived from SKOV3 cell line. Natl Med J Chin. 2016;96(25):2013-6. https://doi.org/10.3760/cma.j.issn.0376-2491.2016.25.012.

159. Ding Q, Chen Y, Zhang Q, Guo Y, Huang Z, Dai L, et al. 8-Bromo-7-methoxychrysin induces apoptosis by regulating Akt/FOXO3a pathway in cisplatin-sensitive and resistant ovarian cancer cells. Mol Med Rep. 2015;12(4):5100-8. https://doi.org/10.3892/mmr.2015.4039.

160. Santos I, Ramos C, Mendes C, Sequeira CO, Tomé CS, Fernandes DGH, et al. Targeting glutathione and cystathionine $\beta$-synthase in ovarian cancer treatment by selenium-chrysin polyurea dendrimer nanoformulation. Nutrients. 2019;11(10). https://doi.org/10.3390/nu11102523.

161. Li HZ, Cao JG, Deng YA, Xu JH, Xie WY. Induction of apoptosis of human ovarian cancer CoC1 cells by 5-Allyl-7-Gen-difluoromethylenechrysin through activation of peroxisome-proliferator activated receptorgamma. Natl Med J Chin. 2007;87(41):2914-8.

162. Qiu HZ, Huang J, Xiang CC, Li R, Zuo ED, Zhang Y, et al. Screening and discovery of new potential biomarkers and small molecule drugs for cervical cancer: a bioinformatics analysis. Technol Cancer Res Treat. 2020;19. https://doi.org/10.1177/1533033820980112.

163. Wahab NH, Mat NFC. Baicalein-rich fraction of Oroxylum indicum leaves induces apoptosis by repressing E6 and E7 expression in HPV-associated cervical cancer cell lines. Int J Res Pharm Sci. 2018;9(Special issue 2):108-17. https://doi.org/10.26452/ijrps.v9iSPL2.1751.

164. Dong W, Chen A, Chao X, Li X, Cui Y, Xu C, et al. Chrysin inhibits proinflammatory factor-induced EMT phenotype and cancer stem cell-like features in HeLa cells by blocking the NF-kB/Twist axis. Cell Physiol Biochem. 2019;52(5):1236-50. https://doi.org/10.33594/000000084

165. Feinshtein V, Holcberg G, Amash A, Erez N, Rubin M, Sheiner E, et al. Nitrofurantoin transport by placental choriocarcinoma JAr cells: involvement of BCRP, OATP2B1 and other MDR transporters. Arch Gynecol Obstet. 2010;281(6):1037-44. https://doi.org/10.1007/ s00404-009-1286-7.

166. Park W, Park S, Lim W, Song G. Chrysin disrupts intracellular homeostasis through mitochondria-mediated cell death in human choriocarcinoma cells. Biochem Biophys Res Commun. 2018;503(4):3155-61. https://doi. org/10.1016/j.bbrc.2018.08.109.

167. Talebi M, Talebi M, Samarghandian S. Association of Crocus sativus with cognitive dysfunctions and Alzheimer's disease: a systematic review. Biointerface Res Appl Chem. 2021. https://doi.org/10.33263/BRIAC111. 74687492.

168. Araújo JR, Gonçalves P, Martel F. Modulation of glucose uptake in a human choriocarcinoma cell line (BeWo) by dietary bioactive compounds and drugs of abuse. J Biochem. 2008;144(2):177-86. https://doi. org/10.1093/jb/mvn054.

169. Li D, Li L, Wang L, Li J, Zhang B. 7-Piperazine ethyl chrysin inhibits proliferation of lung cancer cells via induction of apoptosis. Trop J Pharm Res. 2018;17(10):1919-24. https://doi.org/10.4314/tjpr.v17i10.4.

170. Maruhashi R, Eguchi H, Akizuki R, Hamada S, Furuta T, Matsunaga T, et al. Chrysin enhances anticancer drug-induced toxicity mediated by the reduction of claudin-1 and 11 expression in a spheroid culture model of lung squamous cell carcinoma cells. Sci Rep. 2019;9(1):13753. https:// doi.org/10.1038/s41598-019-50276-Z.

171. Wu TC, Chan ST, Chang CN, Yu PS, Chuang CH, Yeh SL. Quercetin and chrysin inhibit nickel-induced invasion and migration by downregulation of TLR4/NF-KB signaling in A549 cells. Chem Biol Interact. 2018;292:101-9. https://doi.org/10.1016/j.cbi.2018.07.010.

172. Samarghandian S, Nezhad MA, Mohammadi G. Role of caspases, Bax and $\mathrm{BCl}-2$ in chrysin-induced apoptosis in the A549 human lung adenocarcinoma epithelial cells. Anticancer Agents Med Chem. 2014;14(6):901-9. https://doi.org/10.2174/18715206146661402091 44042.

173. Kasala ER, Bodduluru LN, Barua CC, Madhana RM, Dahiya V, Budhani MK, et al. Chemopreventive effect of chrysin, a dietary flavone against benzo(a)pyrene induced lung carcinogenesis in Swiss albino mice. Pharmacol Rep. 2016;68(2):310-8. https://doi.org/10.1016/j.pharep. 2015.08.014.

174. Shao JJ, Zhang AP, Oin W, Zheng L, Zhu YF, Chen X. AMP-activated protein kinase (AMPK) activation is involved in chrysin-induced growth inhibition and apoptosis in cultured A549 lung cancer cells. Biochem Biophys Res Commun. 2012;423(3):448-53. https://doi.org/10.1016/j. bbrc.2012.05.123.

175. Brechbuhl HM, Kachadourian R, Min E, Chan D, Day BJ. Chrysin enhances doxorubicin-induced cytotoxicity in human lung epithelial cancer cell lines: the role of glutathione. Toxicol Appl Pharmacol. 2012;258(1):1-9. https://doi.org/10.1016/j.taap.2011.08.004.

176. Wang HW, Lin CP, Chiu JH, Chow KC, Kuo KT, Lin CS, et al. Reversal of inflammation-associated dihydrodiol dehydrogenases (AKR1C1 and AKR1C2) overexpression and drug resistance in nonsmall cell lung cancer cells by wogonin and chrysin. Int J Cancer. 2007;120(9):2019-27. https://doi.org/10.1002/ijc.22402.

177. Shin H-D, Lee HJ, Sikder M, Park SH, Ryu J, Hong J-H, et al. Effect of chrysin on gene expression and production of MUC5AC mucin from cultured airway epithelial cells. Tuberc Respir Dis (Seoul). 2012;73(4):204-9. https://doi.org/10.4046/trd.2012.73.4.204.

178. Sharifi-Rad J, Rajabi S, Martorell M, López MD, Toro MT, Barollo S, et al. Plant natural products with anti-thyroid cancer activity. Fitoterapia. 2020;146:104640. https://doi.org/10.1016/j.fitote.2020.104640.

179. Granata R, Locati L, Licitra L. Therapeutic strategies in the management of patients with metastatic anaplastic thyroid cancer: review of the current literature. Curr Opin Oncol. 2013;25(3):224-8. https://doi.org/10. 1097/CCO.0b013e32835ff44b.

180. Yu XM, Phan T, Patel PN, Jaskula-Sztul R, Chen H. Chrysin activates Notch1 signaling and suppresses tumor growth of anaplastic thyroid carcinoma in vitro and in vivo. Cancer. 2013;1 19(4):774-81. https://doi. org/10.1002/cncr.27742. 
181. Zhang C, Yu M, Hao F, Dong A, Chen D, Zhang K. Chrysin inhibits growth and induces apoptosis of anaplastic thyroid cancer cells via Notch-1/Slug/PUMA signals. Int J Clin Exp Pathol. 2016;9(9):9038-47.

182. Phan T, Yu XM, Kunnimalaiyaan M, Chen H. Antiproliferative effect of chrysin on anaplastic thyroid cancer. J Surg Res. 2011;170(1):84-8. https://doi.org/10.1016/j.jss.2011.03.064.

183. Wei Y, Zheng Q, Tang G, Song C, Wang G, Zhang Y, et al. Synthesis and anti-thyroid cancer effect of iodo-chrysin derivatives. Med Chem. 2016;12(5):441-7. https://doi.org/10.2174/15734064116661509211 11220.

184. Wang Z, Liang T, Li T, Zhou K. Effect of chrysin in inhibiting proliferation of human nasopharyngeal carcinoma cell line CNE-2. J Chin Pharma Univ. 2013;44(1):93-6.

185. Syed DN, Mukhtar H. Botanicals for the prevention and treatment of cutaneous melanoma. Pigment Cell Melanoma Res. 2011;24(4):688702. https://doi.org/10.1111/j.1755-148X.2011.00851.X.

186. Benguedouar L, Lahouel M, Gangloff SC, Durlach A, Grange F, Bernard $P$, et al. Ethanolic extract of Algerian propolis and galangin decreased murine melanoma T. Anticancer Agents Med Chem. 2016;16(9):117283. https://doi.org/10.2174/1871520616666160211124459.

187. Chen HY, Jiang YW, Kuo CL, Way TD, Chou YC, Chang YS, et al. Chrysin inhibit human melanoma A375.S2 cell migration and invasion via affecting MAPK signaling and NF-KB signaling pathway in vitro. Environ Toxicol. 2019;34(4):434-42. https://doi.org/10.1002/tox.22697.

188. Sassi A, Maatouk M, El Gueder D, Bzéouich IM, Abdelkefi-Ben Hatira S, Jemni-Yacoub S, et al. Chrysin, a natural and biologically active flavonoid suppresses tumor growth of mouse B16F10 melanoma cells: in vitro and in vivo study. Chem Biol Interact. 2018;283:10-9. https://doi. org/10.1016/j.cbi.2017.11.022.

189. Pal-Bhadra M, Ramaiah MJ, Reddy TL, Krishnan A, Pushpavalli SNCVL, Babu KS, et al. Plant HDAC inhibitor chrysin arrest cell growth and induce P21WAF1 by altering chromatin of STAT response element in A375 cells. BMC Cancer. 2012;12. https://doi.org/10.1186/ 1471-2407-12-180.

190. Pichichero E, Cicconi R, Mattei M, Canini A. Chrysin-induced apoptosis is mediated through p38 and Bax activation in B16-F1 and A375 melanoma cells. Int J Oncol. 2011;38(2):473-83. https://doi.org/10.3892/ijo. 2010.876

191. Pichichero E, Cicconi R, Mattei M, Muzi MG, Canini A. Acacia honey and chrysin reduce proliferation of melanoma cells through alterations in cell cycle progression. Int J Oncol. 2010;37(4):973-81. https://doi.org/ 10.3892/ijo_00000748.

192. Tavakoli F, Jahanban-Esfahlan R, Seidi K, Jabbari M, Behzadi R, Pilehvar-Soltanahmadi Y, et al. Effects of nano-encapsulated curcuminchrysin on telomerase, MMPs and TIMPs gene expression in mouse B16F10 melanoma tumour model. Artif Cells Nanomed Biotechnol. 2018;46(sup2):75-86. https://doi.org/10.1080/21691401.2018.1452021.

193. Xue C, Chen Y, Hu DN, lacob C, Lu C, Huang Z. Chrysin induces cell apoptosis in human uveal melanoma cells via intrinsic apoptosis. Oncol Lett. 2016;12(6):4813-20. https://doi.org/10.3892/ol.2016.5251.

194. Jia WZ, Zhao JC, Sun XL, Yao ZG, Wu HL, Xi ZQ. Additive anticancer effects of chrysin and low dose cisplatin in human malignant glioma cell (U87) proliferation and evaluation of the mechanistic pathway. J BUON. 2015;20(5):1327-36.

195. Feng X, Zhou Q, Liu C, Tao ML. Drug screening study using glioma stem-like cells. Mol Med Rep. 2012;6(5):1117-20. https://doi.org/10. 3892/mmr.2012.1040

196. Wang J, Wang H, Sun K, Wang X, Pan H, Zhu J, et al. Chrysin suppresses proliferation, migration, and invasion in glioblastoma cell lines via mediating the ERK/Nrf2 signaling pathway. Drug Des Devel Ther. 2018;12:721-33. https://doi.org/10.2147/DDDT.S160020.

197. Talebi M, Talebi M, Farkhondeh T, Samarghandian S. Biological and therapeutic activities of thymoquinone: focus on the Nrf2 signaling pathway. Phytother Res. 2020. https://doi.org/10.1002/ptr.6905.

198. Weng MS, Ho YS, Lin JK. Chrysin induces G1 phase cell cycle arrest in C6 glioma cells through inducing p21Waf1/Cip1 expression: involvement of p38 mitogen-activated protein kinase. Biochem Pharmacol. 2005;69(12):1815-27. https://doi.org/10.1016/j.bcp.2005.03.011.

199. Somnay YR, Dull BZ, Eide J, Jaskula-Sztul R, Chen H. Chrysin suppresses achaete-scute complex-like 1 and alters the neuroendocrine phenotype of carcinoids. Cancer Gene Ther. 2015;22(10):496-505. https://doi.org/10.1038/cgt.2015.49.

200. Zaric M, Mitrovic M, Nikolic I, Baskic D, Popovic S, Djurdjevic P, et al. Chrysin induces apoptosis in peripheral blood lymphocytes isolated from human chronic lymphocytic leukemia. Anticancer Agents Med Chem. 2015;15(2):189-95. https://doi.org/10.2174/187152061466614 0924123116.

201. Salimi A, Roudkenar MH, Seydi E, Sadeghi L, Mohseni A, Pirahmadi N, et al. Chrysin as an anti-cancer agent exerts selective toxicity by directly inhibiting mitochondrial complex II and V in CLL B-lymphocytes. Cancer Invest. 2017;35(3):174-86. https://doi.org/10.1080/07357907.2016. 1276187.

202. Lin CC, Yu CS, Yang JS, Lu CC, Chiang JH, Lin JP, et al. Chrysin, a natural and biologically active flavonoid, influences a murine leukemia model in vivo through enhancing populations of T-and B-cells, and promoting macrophage phagocytosis and NK cell cytotoxicity. Vivo. 2012;26(4):665-70.

203. Pilátová M, Stupáková V, Varinská L, Šarišský M, Mirossay L, Miroššay A, et al. Effect of selected flavones on cancer and endothelial cells. Gen Physiol Biophys. 2010;29(2):134-43. https://doi.org/10.4149/gpb_2010_ 02_134.

204. Lee SJ, Yoon JH, Song KS. Chrysin inhibited stem cell factor (SCF)/c-Kit complex-induced cell proliferation in human myeloid leukemia cells. Biochem Pharmacol. 2007;74(2):215-25. https://doi.org/10.1016/j.bcp. 2007.04.011.

205. Woo KJ, Yoo YH, Park JW, Kwon TK. BCl-2 attenuates anticancer agentsinduced apoptosis by sustained activation of Akt/protein kinase B in U937 cells. Apoptosis. 2005;10(6):1333-43. https://doi.org/10.1007/ s10495-005-2763-5.

206. Xiao G, Tang X, Yao C, Wang C. Potentiation of arsenic trioxide-induced apoptosis by 8-bromo-7-methoxychrysin in human leukemia cells involves depletion of intracellular reduced glutathione. Acta Biochim Biophys Sin (Shanghai). 2011;43(9):712-21. https://doi.org/10.1093/ abbs/gmr065.

207. Naso L, Ferrer EG, Lezama L, Rojo T, Etcheverry SB, Williams P. Role of oxidative stress in the antitumoral action of a new vanadyI(IV) complex with the flavonoid chrysin in two osteoblast cell lines: relationship with the radical scavenger activity. J Biol Inorg Chem. 2010;15(6):889-902. https://doi.org/10.1007/s00775-010-0652-z.

208. Berenda J, Smöch C, Stadlbauer C, Mittermair E, Taxauer K, Huttary $\mathrm{N}$, et al. Flavonoids distinctly stabilize lymph endothelial-or blood endothelial disintegration induced by colon cancer spheroids SW620. Molecules. 2020;25(9). https://doi.org/10.3390/molecules25092066.

209. Prangsaengtong O, Athikomkulchai S, Xu J, Koizumi K, Inujima A, Shibahara $\mathrm{N}$, et al. Chrysin inhibits lymphangiogenesis in vitro. Biol Pharm Bull. 2016;39(4):466-72. https://doi.org/10.1248/bpb.b15-00543.

210. Lin CM, Shyu KG, Wang BW, Chang H, Chen YH, Chiu JH. Chrysin suppresses IL-6-induced angiogenesis via down-regulation of JAK1/ STAT3 and VEGF: an in vitro and in ovo approach. J Agric Food Chem. 2010;58(11):7082-7. https://doi.org/10.1021/jf100421w.

211. Lin CM, Chang H, Li SY, Wu IH, Chiu JH. Chrysin inhibits lipopolysaccharide-induced angiogenesis via down-regulation of VEGFNEGFR-2(KDR) and IL-6/L-6R pathways. Planta Med. 2006;72(8):708-14. https://doi.org/ 10.1055/s-2006-931602.

212. Orsolić N, Kosalec I, Basić I. Synergistic antitumor effect of polyphenolic components of water soluble derivative of propolis against Ehrlich ascites tumour. Biol Pharm Bull. 2005;28(4):694-700. https://doi.org/10, 1248/bpb.28.694.

213. Sun LP, Chen AL, Hung HC, Chien YH, Huang JS, Huang CY, et al. Chrysin: a histone deacetylase 8 inhibitor with anticancer activity and a suitable candidate for the standardization of Chinese propolis. J Agric Food Chem. 2012;60(47):11748-58. https://doi.org/10.1021/jf303261r.

214. Ramachandran S, Shanmugam M. Chemopreventic potential of chrysin in 7,12-dimethylbenz(a)anthracene induced mammary carcinogenesis in Sprague-Dawley rats. J Cell Tissue Res. 2011;11:2909-18.

215. Karthikeyan S, Ramachandran S, Wani SA, Shanmugam M. Chemopreventive potential of chrysin in 7,12-dimethylbenz(a)anthraceneinduced hamster buccal pouch carcinogenesis. Int J Nutr Pharmacol Neurol Dis. 2013;3:46-53. https://doi.org/10.4103/2231-0738.106993.

216. Sequetto PL, Oliveira TT, Soares IA, Maldonado IR, Mello VJ, Pizziolo $V R$, et al. The flavonoid chrysin attenuates colorectal pathological 
remodeling reducing the number and severity of pre-neoplastic lesions in rats exposed to the carcinogen 1,2-dimethylhydrazine. Cell Tissue Res. 2013;352(2):327-39. https://doi.org/10.1007/s00441-013-1562-5.

217. Miyamoto S, Kohno H, Suzuki R, Sugie S, Murakami A, Ohigashi H, et al. Preventive effects of chrysin on the development of azoxymethane-induced colonic aberrant crypt foci in rats. Oncol Rep. 2006;15(5):1169-73.

218. Quan MF, Xiao LH, Liu ZH, Guo H, Ren KQ, Liu F, et al. 8-Bromo-7-methoxychrysin inhibits properties of liver cancer stem cells via downregulation of $\beta$-catenin. World J Gastroenterol. 2013;19(43):7680-95. https:// doi.org/10.3748/wjg.v19.i43.7680.

219. Liu H, Hwang J, Li W, Choi TW, Liu K, Huang Z, et al. A derivative of chrysin suppresses two-stage skin carcinogenesis by inhibiting mitogenand stress-activated kinase 1. Cancer Prev Res (Phila). 2014;7(1):74-85. https://doi.org/10.1158/1940-6207.CAPR-13-0133.

220. Liu H, Liu K, Huang Z, Park CM, Thimmegowda NR, Jang JH, et al. A chrysin derivative suppresses skin cancer growth by inhibiting cyclindependent kinases. J Biol Chem. 2013;288(36):25924-37. https://doi. org/10.1074/jbc.M113.464669.

221. Kanwal R, Datt M, Liu X, Gupta S. Dietary flavones as dual inhibitors of DNA methyltransferases and histone methyltransferases. PLoS ONE. 2016;11(9):e0162956. https://doi.org/10.1371/journal.pone.0162956.

222. Monasterio A, Urdaci MC, Pinchuk IV, López-Moratalla N, Martínez-Irujo JJ. Flavonoids induce apoptosis in human leukemia U937 cells through caspase- and caspase-calpain-dependent pathways. Nutr Cancer. 2004;50(1):90-100. https://doi.org/10.1207/s15327914nc5001_12.

223. Woo KJ, Jeong YJ, Park JW, Kwon TK. Chrysin-induced apoptosis is mediated through caspase activation and Akt inactivation in U937 leukemia cells. Biochem Biophys Res Commun. 2004;325(4):1215-22. https://doi. org/10.1016/j.bbrc.2004.09.225.

224. von Brandenstein MG, Ngum Abety A, Depping R, Roth T, Koehler M, Dienes HP, et al. A p38-p65 transcription complex induced by endothelin-1 mediates signal transduction in cancer cells. Biochim Biophys Acta. 2008;1783(9):1613-22. https://doi.org/10.1016/j.bbamcr.2008.04.003.

225. Patel RV, Mistry B, Syed R, Rathi AK, Lee YJ, Sung JS, et al. Chrysin-piperazine conjugates as antioxidant and anticancer agents. Eur J Pharm Sci. 2016;88:166-77. https://doi.org/10.1016/j.ejps.2016.02.011.

226. Gülden M, Appel D, Syska M, Uecker S, Wages F, Seibert H. Chrysin and silibinin sensitize human glioblastoma cells for arsenic trioxide. Food Chem Toxicol. 2017;105:486-97. https://doi.org/10.1016/j.fct.2017.04. 035.

\section{Publisher's Note}

Springer Nature remains neutral with regard to jurisdictional claims in published maps and institutional affiliations.
Ready to submit your research? Choose BMC and benefit from:

- fast, convenient online submission

- thorough peer review by experienced researchers in your field

- rapid publication on acceptance

- support for research data, including large and complex data types

- gold Open Access which fosters wider collaboration and increased citations

- maximum visibility for your research: over 100M website views per year

At BMC, research is always in progress.

Learn more biomedcentral.com/submissions 